\title{
A BIBLIOMETRIC DATA ANALYSIS OF MULTI-CRITERIA DECISION MAKING METHODS IN HERITAGE BUILDINGS
}

\author{
Žydrūnè MORKŪNAITĖ ${ }^{1}$, Darius KALIBATAS ${ }^{1}$, Diana KALIBATIENE $\dot{2}^{2}$ \\ ${ }^{1}$ Department of Construction Management and Real Estate, Vilnius Gediminas Technical University, \\ Vilnius, Lithuania \\ ${ }^{2}$ Department of Information Systems, Vilnius Gediminas Technical University, Vilnius, Lithuania
}

Received 20 November 2018; accepted 09 January 2019

\begin{abstract}
Numerous countries are trying to find the best solution for conservation, restoration or reuse of the heritage buildings, preserving their cultural, historical, ethnic and spiritual values. The scientists, researchers and government are analysing the problems concerning with heritage building's, like seismic issues, energy saving, sustainability, structures, materials and adaptive reuse. Since, heritage buildings' reuse and preservation are characterized by multiple criteria, a multi-criteria decision making (MCDM) methods are useful in finding rational solutions for the previously mentioned problems. The current paper aims to overview papers on the MCDM approaches application in regard to heritage buildings' reuse and preservation area. This study employs a bibliometric data analysis to explore state-of-the-art of the defined topic and an in-deep analysis - to synthesize the knowledge domain and critically evaluate a thorough literature in the analysed topic. As a result, scientific maps were created to reveal the knowledge domain of MCDM approaches in heritage buildings' reuse and preservation. Finally, research gaps and future research directions are identified. Results of the analysis shows that till now MCDM approaches are not widely used in solving heritage buildings reuse and preservation issues. Moreover, there is luck of complex problem solving approach in cultural heritage buildings area.
\end{abstract}

Keywords: heritage building, historic building, multi-criteria decision-making, multi-criteria analysis, AHP, fuzzy analysis, MCDM, literature review.

\section{Introduction}

Cultural heritage is a fundamental of irreplaceable spiritual, cultural, archaeological, historical, ethnic, mythological, social, economic and technical, technological value. Cultural heritage buildings usually have listed valuable properties, which must be preserved when refurbishing the building and reused for social and cultural goals. However, the refurbishment measures, which can be applied in cultural heritage buildings, are much more limited due to preservation of valuable properties of these buildings. Cultural heritage buildings differ from other buildings in two primary ways that can affect their preservation: 1) physical characteristics, as these buildings may have complex and unusual geometry, envelope construction lacking insulation layer, national construction methods and natural non-standardized materials used for construction of these buildings are heterogeneous in their composition, passive and natural ventilation is used; 2) conservation principles, as the refurbishment of cultural heritage buildings is governed by established conservation principles and practices, which require the protection of a historical value and distinguishing characters of a building (Webb, 2017). Since these differences, refurbishment used in newer and modern buildings may not be suitable for and may cause damage to cultural and traditionally constructed buildings, resulting in loss of cultural heritage.

The scientists, researchers and government are analyzing the problems concerning with heritage building's seismic issues, energy saving, sustainability, structures, materials and adaptive reuse. Since, cultural heritage buildings' reuse and preservation are characterized by multiple criteria, a multi-criteria decision making (MCDM) methods can be applied in finding rational solutions for cultural heritage buildings' reuse and preservation.

The current paper aims to overview papers on the application and use of MCDM approaches in regard to heritage buildings' reuse and preservation area. The last part of

*Corresponding author. E-mail: diana.kalibatiene@vgtu.lt 
the paper is structured as follows. Section 1 presents related works on MCDM approaches application in regard to solving cultural heritage buildings issues and existing review studies on this topic. Section 2 presents a research methodology used in this paper. Section 3 presents obtained results of the study. Section 4 discusses the obtained results and the last section concludes the paper.

\section{Related works}

Heritage buildings present countries' and their communities' history and identity, which transmitted from generation to generation. Therefore, their conservation and restoration is the essential task of numerous countries. Over the last five years (2014-2018) a number of review papers have been presented dealing with historical and heritage buildings reuse and preservation. Fung, Tsang, Tam, Xu, and Mok (2017) analyzed historic building conservation. Gomes, Dionísio, and Pozo-Antonio (2017) and Sanmartín, Cappitelli, and Mitchell (2014) presented cleaning methods against graffiti vandalism. Meanwhile, Pozo-Antonio, Rivas, López, Fiorucci, and Ramil (2016) analyzed granite cleaning process. Much attention is being paid to heritage buildings structures, such as stainless steel for masonry repair and reinforcement (Corradi, Di Schino, Borri, \& Rufini, 2018), assessment of heritage timber structures (Riggio, D’Ayala, Parisi, \& Tardini, 2018). Moreover, authors analyzing seismic problems in heritage buildings, such as earthquake resistant techniques (Ortega, Vasconcelos, Rodrigues, Correia, \& Lourenço, 2017). There are a number of review papers, in which researchers study heritage buildings issues based on integration of renewable technologies (Cabeza, de Gracia, \& Pisello, 2018), sustainability in heritage (Sigmund, 2016), adaptive reuse in sustainable development (Tam, Fung, \& Sing, 2016), energy efficiency (Berg, Flyen, Godbolt, \& Broström, 2017; Gregório \& Seixas, 2017; Webb, 2017; Martínez-Molina, Tort-Ausina, Cho, \& Vivancos, 2016). Applications of Building Information Modelling (BIM) for heritage science (Pocobelli, Boehm, Bryan, Still, \& Grau-Bové, 2018), nanomaterials application in preservation and restoration of stony materials (Sierra-Fernandez, Gomez-Villalba, Rabanal, \& Fort, 2017) are presented.

Other important part of a topic in this research is concerning multi-criteria decision making (MCDM) methods. The usefulness of MCDM methods is recognized in a number of papers. They have been applied in different areas, like in health risk assessment (Habib, Makhoul, Darazi, \& Couturier, 2019), expert and intelligent systems (He \& Xu, 2019), statistical analysis (Krylovas, Kosareva, \& Zavadskas, 2018), the success of performance appraisal (Maghsoodi, Abouhamzeh, Khalilzadeh, \& Zavadskas, 2018), sustainable energy development issues (Siksnelyte, Zavadskas, Streimikiene, \& Sharma, 2018), transportation (Radović et al., 2018), solving multi-criteria group decision making problems (Krishankumar et al., 2018), to assess air pollution (Zavadskas et al., 2018). Other of them are as follows: sustainability issues are analyzed (Shen, Zavads- kas, \& Tzeng, 2018; Zavadskas, Antucheviciene, Vilutiene, \& Adeli, 2017; Zavadskas, Govindan, Antucheviciene, \& Turskis, 2016), energy efficient (Kaya, Çolak, \& Terzi, 2018; Cajot, Mirakyan, Koch, \& Maréchal, 2017; Mardani et al., 2017a, 2017b) and renewable energy (Lee \& Chang, 2018; Colak \& Kaya, 2017; Kumar et al., 2017; Strantzali \& Aravossis, 2016), green supply chain (Banasik, Bloemhof-Ruwaard, Kanellopoulos, Claassen, \& van der Vorst, 2018), green technologies (Si, Marjanovic-Halburd, Nasiri, \& Bell, 2016), a material choice for natural fiber composites (Noryani, Sapuan, \& Mastura, 2018), sustainable material selection (Govindan, Shankar, \& Kannan, 2016). de Almeida, Alencar, Garcez, and Ferreira (2017) analyzed MCDM approaches in risk management. Zavadskas, Antucheviciene, Turskis, and Adeli (2016) presented hybrid MCDM review in engineering field; Mardani et al. (2017a) reviewed SWARA and WASPAS methods; Ameyaw, Hu, Shan, Chan, and Le (2016) reviewed application of Delphi in construction engineering and management research. Gul, Celik, Aydin, Gumus, and Guneri (2016), Mardani, Zavadskas, Govindan, Amat Senin, and Jusoh (2016), Kang and Park (2014) have presented review of VIKOR. Govindan and Jepsen (2016) have analyzed ELECTRE techniques. Valipour, Yahaya, Md Noor, Antuchevičiené, and Tamošaitienè (2017) have applied SWARA-COPRAS method for risk assessment in deep foundation excavation project. Han and Wang (2018) applied grey DEMATEL in identifying barriers in off-site construction. Fuzzy MCDM was discussed by Mardani, Jusoh, and Zavadskas (2015) and applied for project risk evaluation by Asadi, Rezaeian Zeidi, Mojibi, Yazdani-Chamzini, and Tamošaitienè (2018). Shariati et al. (2017) applied fuzzy ANP in evaluating critical factors of nanotechnology in construction industry.

All mentioned and existing researches in different areas argue usefulness of MCDM methods as a valuable tool for decision makers. In this paper authors analyze usage of MCDM methods in heritage area for solving different problems. The authors of this paper understand MCDM as defined by Triantaphyllou (2000). We are not focusing on a particular MCDM method; however, use particular names of MCDM methods to make our search for relevant sources more meaningful.

Clearly, like every other approach, MCDM methods also have their own disadvantages and limitations. Govindan, Rajendran, Sarkis, and Murugesan (2015) identify that AHP limitation is that in different industries indices vary and may affect the conclusions. Ho, $\mathrm{Xu}$, and Dey (2010), Özcan, Çelebi, and Esnaf (2011) identify the drawbacks of MCDM methods as follows: confusion with input-output criteria; the subjective evaluation of qualitative criteria; time-consumption in reaching consensus, like may be in AHP which uses pairwise comparison matrices; luck of consistency, like in TOPSIS, ELECTRE I and ELECTRE II methods. Moreover, according to Aruldoss, Lakshmi, and Venkatesan (2013), not all MCDM methods allow assignment of interval values to attributes. Kumar et al. (2017) presented a review of MCDM methods usage in sustain- 
Table 1. Summary of previous studies on MCDM methods application in solving different problems in cultural heritage building area

\begin{tabular}{|l|c|l|l|l|l|l|l|}
\hline Reference & $\begin{array}{c}\text { Review } \\
\text { period } \\
\text { in years }\end{array}$ & $\begin{array}{c}\text { Method of } \\
\text { analysis and } \\
\text { tools used }\end{array}$ & $\begin{array}{c}\text { Number of analysed } \\
\text { papers }\end{array}$ & Databases & Focus of the study & $\begin{array}{c}\text { MCDM } \\
\text { method applied }\end{array}$ & $\begin{array}{c}\text { Main } \\
\text { findings }\end{array}$ \\
\hline 1. & 2. & 3. & 4. & 5. & 6. & 7. \\
\hline $\begin{array}{l}\text { Berg et al. } \\
(2017)\end{array}$ & - & Manual & - & - & $\begin{array}{l}\text { user-driven energy } \\
\text { efficiency in historic } \\
\text { buildings }\end{array}$ & SK, RG \\
\hline $\begin{array}{l}\text { Chen, } \\
\text { Chiu, and } \\
\text { Tsai }\end{array}$ & - & Manual & $\begin{array}{l}\text { Papers and case } \\
\text { studies }\end{array}$ & - & $\begin{array}{l}\text { the adaptive reuse } \\
\text { of historic buildings } \\
\text { through MCDM }\end{array}$ & $\begin{array}{l}\text { The analytic } \\
\text { hierarchy } \\
\text { process (AHP), } \\
\text { Fuzzy Delphi } \\
\text { method (FDM) }\end{array}$ & $\begin{array}{l}\text { a decision- } \\
\text { making } \\
\text { model }\end{array}$ \\
\hline $\begin{array}{l}\text { Lucchi } \\
\text { (2016) }\end{array}$ & - & Manual & $\begin{array}{l}\text { Papers, case studies, } \\
\text { collected data, } \\
\text { technical studies, } \\
\text { standards, practices, } \\
\text { and policies }\end{array}$ & - & $\begin{array}{l}\text { the decision making } \\
\text { process on conservation, } \\
\text { energy efficiency, and } \\
\text { human comfort in } \\
\text { museum buildings }\end{array}$ & $\begin{array}{l}\text { the SOBANE } \\
\text { strategy }\end{array}$ & $\begin{array}{l}\text { a method } \\
\text { for EEP } \\
\text { assessment } \\
\text { in museum } \\
\text { buildings }\end{array}$ \\
\hline $\begin{array}{l}\text { Munarim } \\
\text { and Ghisi } \\
\text { (2016) }\end{array}$ & $\begin{array}{l}1970- \\
2017\end{array}$ & Manual & $\begin{array}{l}\text { he most recent } \\
\text { works }\end{array}$ & - & $\begin{array}{l}\text { heritage buildings } \\
\text { rehabilitation }\end{array}$ & SK \\
\hline
\end{tabular}

able renewable energy development. The following limitations have been observed within MCDM methods (Kumar et al., 2017): the failure in calculation of dynamic weights of the criteria in TOPSIS (Zhou \& Lu, 2012); the failure of integrating multiple preferences in Weighted Sum Method (WSM); undesirable results when priorities or deprioritise the alternative which is far from average in Weighted Product Method (WPM); complex assignment of weights and complicated data collection based on experience in AHP; ELECTRE not universal and hard understandable; not difference between negative and positive values and attribute values should be monotonically increasing or decreasing in TOPSIS; VICOR difficult with conflicting situations and difficult to model a real time model. However, the mentioned drawbacks of MCDM methods are solved by applying hybrid methods, like fuzzy sets and TOPSIS.

MCDM methods application in solving different multi-dimensional problems in cultural heritage building area is also known. Some of them are presented in Table 1. As can be seen from the table, authors of this paper present each study according to the review period (Column 2), methods and tools used in the review (Column 3), number of analyzed papers (Column 4), databases used as a source of papers (Column 5), focus of the study (Column 6), MCDM method applied (Column 7) and main findings (Column 8). The main findings of analyzed studies are characterized on literature review contributions, proposed by Schryen, Wagner, and Benlian (2015). In this paper the following categorization, based on the obtained results, of reviews is used: systematizing knowledge in the analyzed area (SK), research gaps (RG), research trends and directions (RT), proposing a framework to close particular gaps (F) or a knowledge map or a network (KM).

As can be seen, an analysis of existing review studies on MCDM methods application in cultural heritage buildings area is not rich. Therefore, there is a need for comprehensive study of using MCDM methods in cultural heritage buildings area.

Since, we are going to use a bibliometric data analysis in our study, particular misuse and limitations of bibliometric data analysis are reviewed here. As presented in a number of papers, in the context of bibliometric data analysis, attention should be paid to proper uses and misuses. Moreover, as stated in Hammarfelt and Rushforth (2017), indicators are always constantly modified, (re)created, and criticized in the contexts of their usage. Haustein and Larivière (2015), have identified several reasons of improper use of bibliometric indicators. They are as follows: a) publishing in journals that count, b) salami slicing, duplicate publishing or self-plagiarism, c) honorary authorship and ghost authorship, d) self-citations, e) increasing the journal impact factor, and f) cumulative or personal impact factors. Moreover, as presented in Haustein and Larivière (2015), Rijcke, Wouters, Rushforth, Franssen, and Hammarfelt (2016), the usage of bibliometric indicators to evaluate research outputs and for funding and hiring decisions, foster unethical behavior of authors. Summing up, this research is necessary for our future studies in applying MCDM in heritage buildings area. Moreover, an in-deep analysis is used to supplement the bibliometric data analysis results in this research.

\section{Research methodology}

In this section, a methodology of reviewing papers on MCDM application in cultural heritage buildings area is presented. The review process is presented in Figure 1.

1. Define a research question. A research questions is defined in this step. According to Merschbrock and Munkvold (2012), Arksey and O’Malley (2005), this 


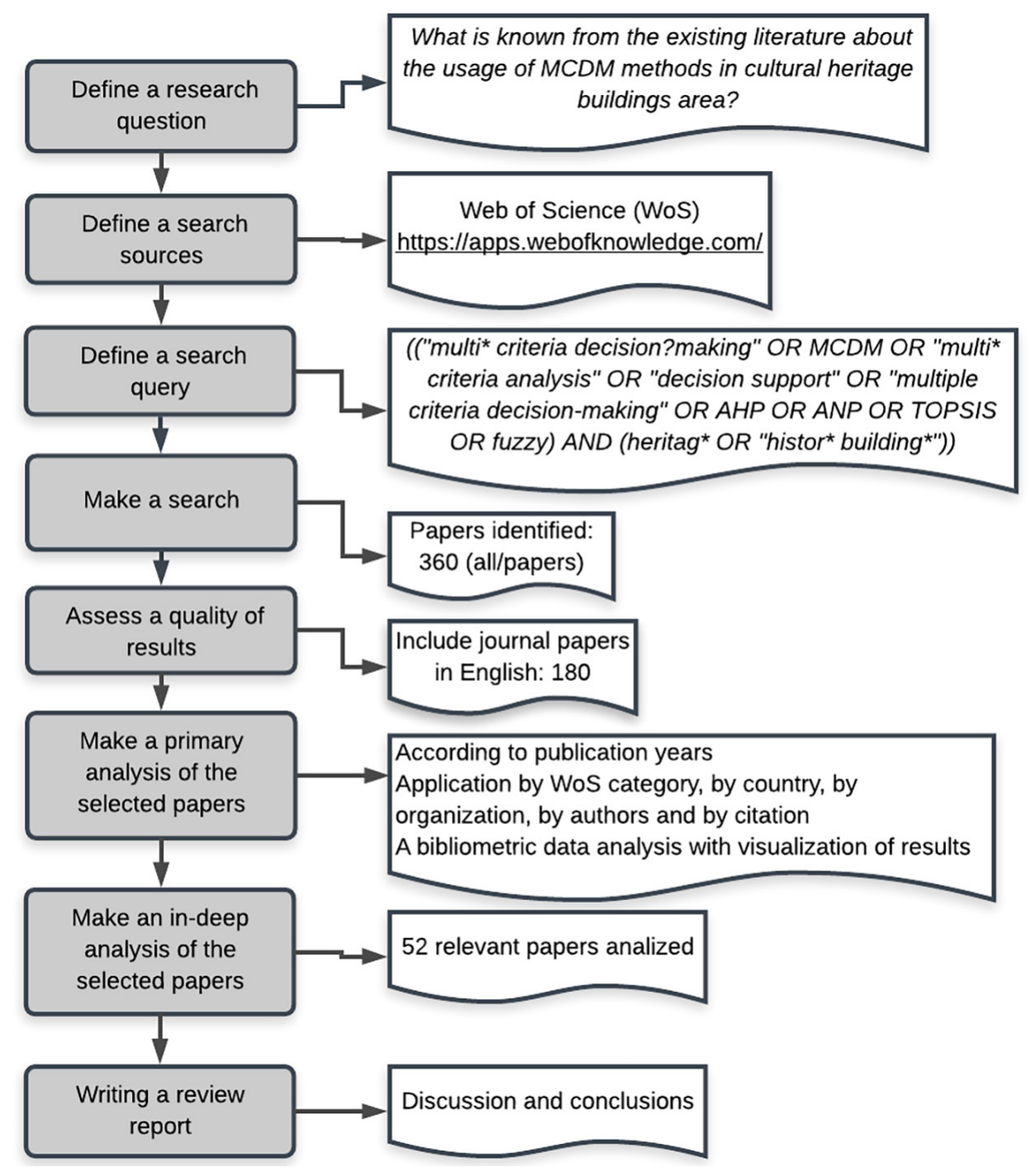

Figure 1. The methodology on the MCDM methods application in cultural heritage buildings area schema

study is a scoping study ${ }^{1}$ and designed to examine the available journal papers and to determine the range of spreading and using of MCDM methods in cultural heritage buildings area. Our research question is: What is known from the existing literature about the usage of MCDM methods in cultural heritage buildings area?

2. Define a search sources. In order to review a certain amount of papers on MCDM methods application in cultural heritage buildings area, the Thomson Reuters Web of Science (WoS) (https://apps.webofknowledge.com/) core database was chosen, since the initial study of sources shows that it contains significant number of journal papers relevant to the research field. This justified the use of WoS as the source for data retrieval.

\footnotetext{
${ }^{1}$ A scoping study is designed in Arksey and O'Malley (2005): 1) to examine the extent, range and nature of research activity;

2) to determine the value of undertaking a full systematic review;

3) to summarise and disseminate research findings; 4) to identify research gaps in the existing literature.
}

3. Define a search query. Searching keywords and their meaningful combinations are defined here. The following search query has been conducted from keywords:

(("multi* criteria decision?making" OR MCDM OR "multi* criteria analysis" OR "decision support" $O R$ "multiple criteria decision-making" OR AHP OR ANP OR TOPSIS OR fuzzy) AND (heritag* OR "histor* building*"))

Note that into the search we have included the keywords AHP, ANP, TOPSIS and fuzzy, since according to Mardani et al. (2017); Zavadskas, Govindan, Antucheviciene, and Turskis (2016); Zavadskas et al. (2017), those methods and their extensions are among the most used MCDM methods in civil engineering, construction and building technology and sustainability. Therefore, their inclusion into the search query allows making a set of obtained results bigger.

4. Make a search. The searching process is performed according to the defined query in step 3. A set of 360 papers is obtained. 


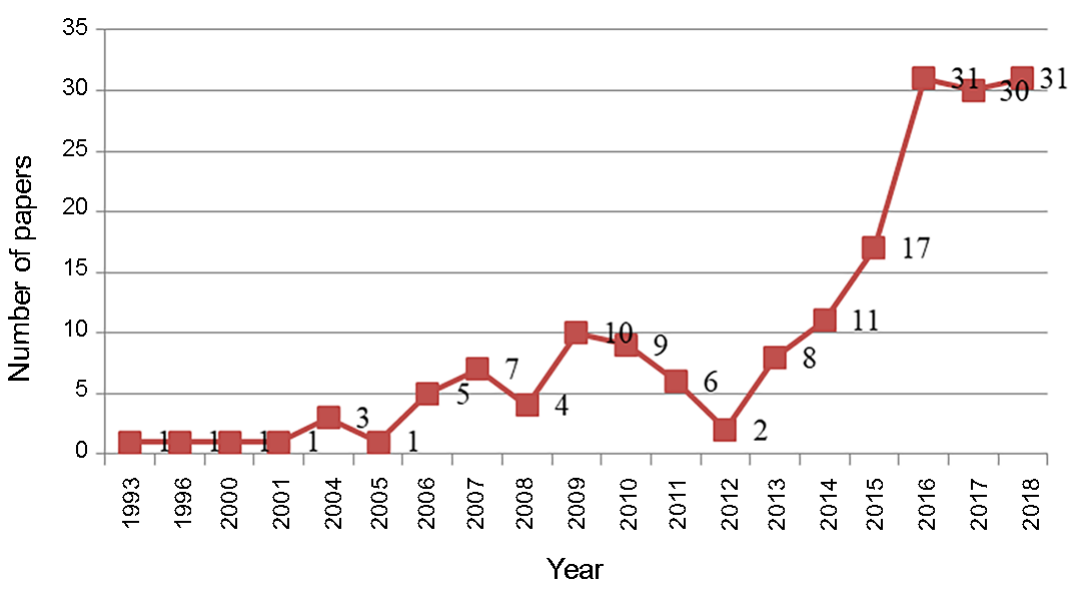

Figure 2. Overview of papers on MCDM methods application in cultural heritage buildings area according to years (WoS, 11 November 2018)

5. Assess a quality of results. Quality of results is assessed here. According to Kitchenham, Mendes, and Travassos (2007) there is no commonly agreed definition of "quality". Moreover, authors of this paper have refined the initial search results by including only papers from journals published in English language. The primary set of publications is refined to 180 papers.

6. Make a primary analysis of papers. A required data is extracted according to the research question. $\mathrm{Pa}$ pers are reviewed according to publication years and application by WoS category, by country, by organization, by authors and by citation. A bibliometric data analysis with visualization of results is performed. Moreover, during this step, papers for the in-deep analysis are selected.

A number of tools, like VOSviewer, BibExcel, CiteSpace, CoPalRed, Sci2, VantagePoint and Gephi, are created for analyzing, mapping and visualization of a bibliometric data. We are not going to make a detailed review of visualization tools, because it is not the main aim of this paper. We are going to use VOSviewer ${ }^{2}$ and $\mathrm{Gephi}^{3}$, as advocated in Hosseini, Martek, Zavadskas, Aibinu, Arashpour, and Chileshe (2018).

7. Make an in-deep analysis of the papers. In this step, an in-deep analysis of the selected papers is performed by reading a full text of the selected papers.

8. Writing a review report. A review report is written and discussion is conducted.

\section{Results of the analysis}

In this section, the analysis results are presented.

\footnotetext{
2 http://www.vosviewer.com/download

${ }^{3}$ https://gephi.org/
}

\subsection{A primary analysis of papers on MCDM methods application in cultural heritage buildings area}

As can be seen from Figure 2, MCDM methods application in cultural heritage buildings are becoming more relevant in civil engineering, construction and building technology. In 2013-2018 a number of papers has increased.

In Figure 3, a comparison of two topics: MCDM methods application in cultural heritage buildings area and cultural heritage buildings, are presented. This figure allows us to evaluate MCDM methods application in cultural heritage buildings topic with more general topic of the cultural heritage buildings. As can be seen from Figure 3, the topic of cultural heritage buildings is widely analyzed in WoS categories as follows: engineering civil, construction building technology, materials science multidisciplinary, architecture, computer science interdisciplinary applications and computer science theory methods.

Considering that applications on topic of "heritage building" and "historic building" (1980-2018) have been published more than 1039 journal papers in English, the use of MCDM methods to deal with heritage buildings consisted only $17 \%$ of total number. The biggest part of papers was published in 2016. Further, we present analysis of MCDM methods application in cultural heritage building area only.

The main considered categories of MCDM methods application in cultural heritage building area are presented in Figure 4. As can be seen from the figure, the five most popular WoS Categories are as follows: Environmental Sciences (32), Geosciences Multidisciplinary (30), Environmental Study (26), Engineering Civil (20) and Archaeology (18).

The bibliometric analysis of papers on MCDM methods application in cultural heritage buildings area according to countries (Figure 5) shows that the main five, working in the analyzed topic, countries are as follows: Italy (29), Australia (19), China (18), Spain (12) and Taiwan (12). Moreover, those countries cite each other. However, 


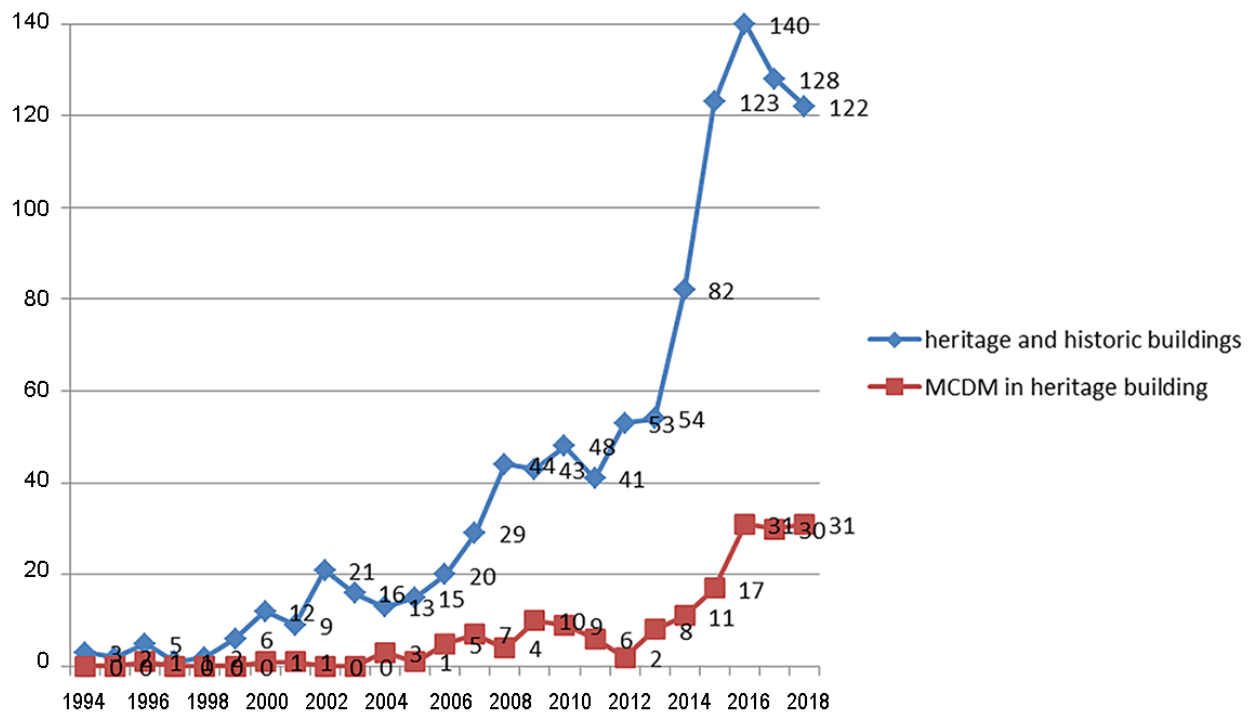

Figure 3. Comparing the topics of cultural heritage buildings with MCDM methods application in cultural heritage buildings area according to the number of papers published during the period of 1994-2018 (WoS, 11 November 2018)

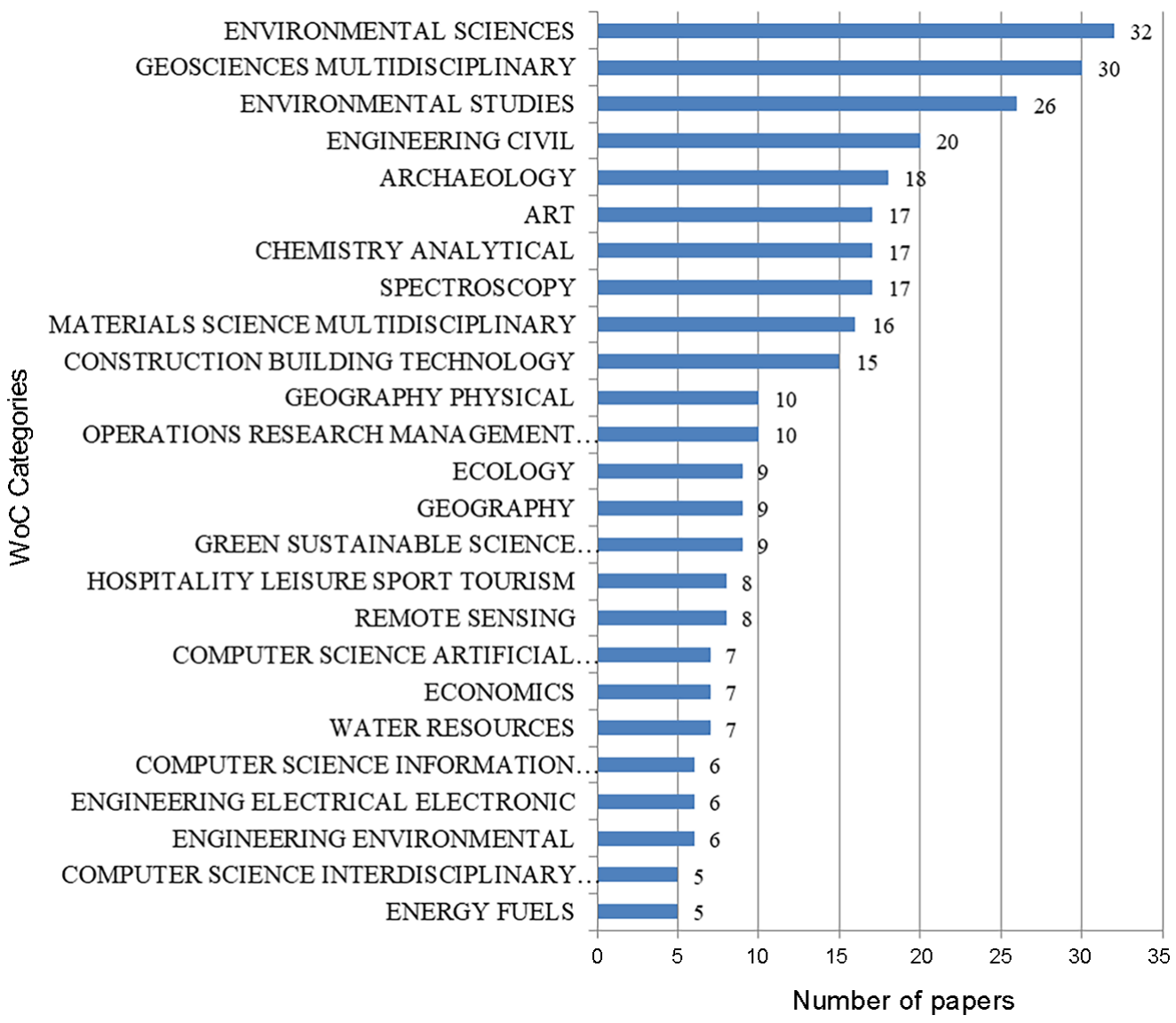

Figure 4. Overview of papers on MCDM methods application in cultural heritage buildings area according to WoS Category (WoS, 11 November 2018) 
iceland

norwey

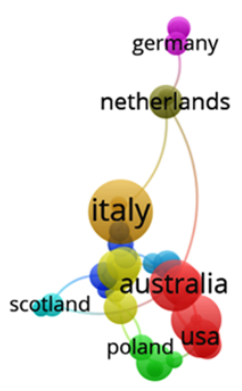

brazil

croatia

south africa

irland

czecto republic

Figure 5. A map of MCDM methods application in cultural heritage buildings area according to countries

(WoS, 11 November 2018)

as can be seen from Table 2, the distribution of priorities of countries according to the citation differs. The most five cited countries are as follows: Lithuania (314), Australia (288), Italy (153), Taiwan (150) and China (111).

This distribution of countries can be explained by a significant number of heritage buildings and traditional dwellings finding in analyzed countries, like in Europe countries. These countries appreciating their heritage sites and buildings, so the government, scientists, researchers are searching qualitative methods how properly to preserve this heritage.

A bibliometric data analysis of papers on MCDM methods application in cultural heritage buildings area according to organizations (Figure 6) shows that the main five organizations are as follows: Vilnius Gediminas Tech Univ (9), Chinese Acad Sci (7), Univ Seville (5), Alexandru Ioan Cuza Univ (4) and Sichuan Univ (4).

Table 3 presents an overview of MCDM methods application in cultural heritage buildings area according to organizations by number of papers and citations. The most cited five organizations are as follows: Vilnius Gediminas Tech Univ (276), Natl Taiwan Univ Sci Technol (80), Csiro Sustainable Ecosyst (79), James Cook Univ N Queensland (71) and Univ Gothenburg (63).

A co-authorship analysis of authors working in the topic of MCDM methods application in cultural heritage buildings is presented in Figure 6. It shows that the most papers having five authors are as follows: Kutut, V. (4), Turskis, Z. (4), Zavadskas, E. K. (4), De Toro, P. (3)
Table 2. Overview of MCDM methods application in cultural heritage buildings area according to countries

(WoS, 11 November 2018)

\begin{tabular}{|l|c|c|}
\hline \multicolumn{1}{|c|}{ Country } & Number of papers & Number of citations \\
\hline Lithuania & 10 & 314 \\
\hline Australia & 19 & 288 \\
\hline Italy & 29 & 153 \\
\hline Taiwan & 12 & 150 \\
\hline China & 18 & 111 \\
\hline USA & 11 & 105 \\
\hline Portugal & 9 & 101 \\
\hline Turkey & 8 & 95 \\
\hline Sweden & 2 & 72 \\
\hline Spain & 12 & 65 \\
\hline South Korea & 6 & 64 \\
\hline Wales & 3 & 47 \\
\hline Poland & 5 & 42 \\
\hline Latvia & 1 & 42 \\
\hline Scotland & 4 & 41 \\
\hline England & 6 & 37 \\
\hline Netherlands & 8 & 35 \\
\hline Colombia & 1 & 34 \\
\hline Finland & 2 & 33 \\
\hline India & 2 & 31 \\
\hline & & \\
\hline
\end{tabular}

Table 3. Overview of MCDM methods application in cultural heritage buildings area according to organizations

(WoS, 11 November 2018)

\begin{tabular}{|l|c|c|}
\hline \multicolumn{1}{|c|}{ Organization } & $\begin{array}{c}\text { Number } \\
\text { of papers }\end{array}$ & $\begin{array}{c}\text { Number of } \\
\text { citations }\end{array}$ \\
\hline Vilnius Gediminas Tech Univ & 9 & 276 \\
\hline Natl Taiwan Univ Sci Technol & 3 & 80 \\
\hline Csiro Sustainable Ecosyst & 3 & 79 \\
\hline James Cook Univ N Queensland & 1 & 71 \\
\hline Univ Gothenburg & 1 & 63 \\
\hline Univ Tras os Montes \& Alto Douro & 1 & 56 \\
\hline Chinese Acad Sci & 7 & 52 \\
\hline Sichuan Univ & 4 & 49 \\
\hline Seoul Natl Univ & 2 & 45 \\
\hline Csiro & 2 & 43 \\
\hline Riga Tech Univ & 1 & 42 \\
\hline Swansea Metropolitan Univ & 2 & 40 \\
\hline Acad Sinica & 1 & 36 \\
\hline Natl Univ Tainan & 1 & 36 \\
\hline Warsaw Univ Technol & 2 & 34 \\
\hline
\end{tabular}

and Nicu, I. C. (3). Figure 7 shows that there are 76 main clusters, covering research groups, which are working in the area of MCDM methods application in cultural heritage buildings area.

In Table 4, an overview of MCDM methods application in cultural heritage buildings area according to the 


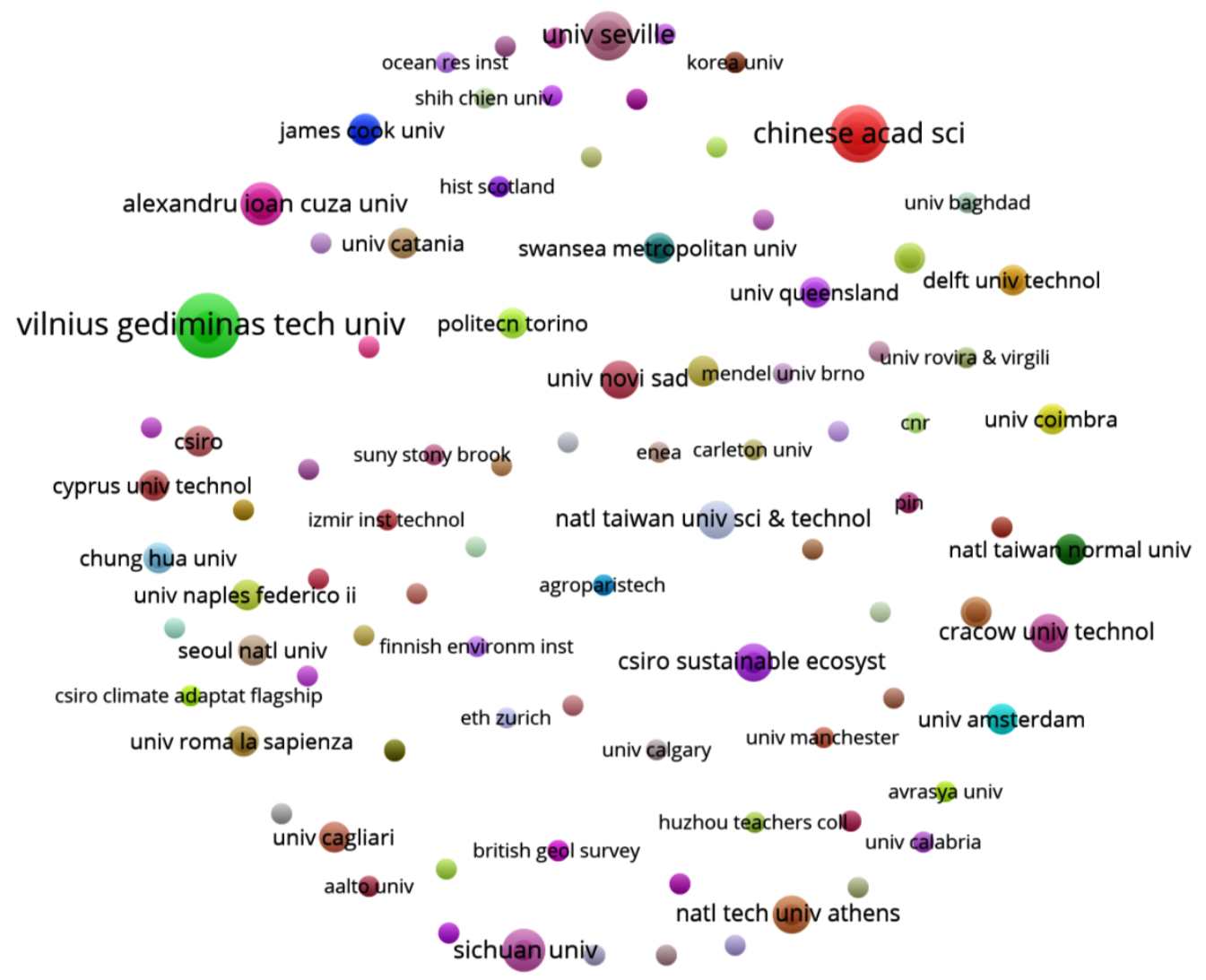

Figure 6. A map of MCDM methods application in cultural heritage buildings area according to organizations (WoS, 11 November 2018)

\& Vosviewer

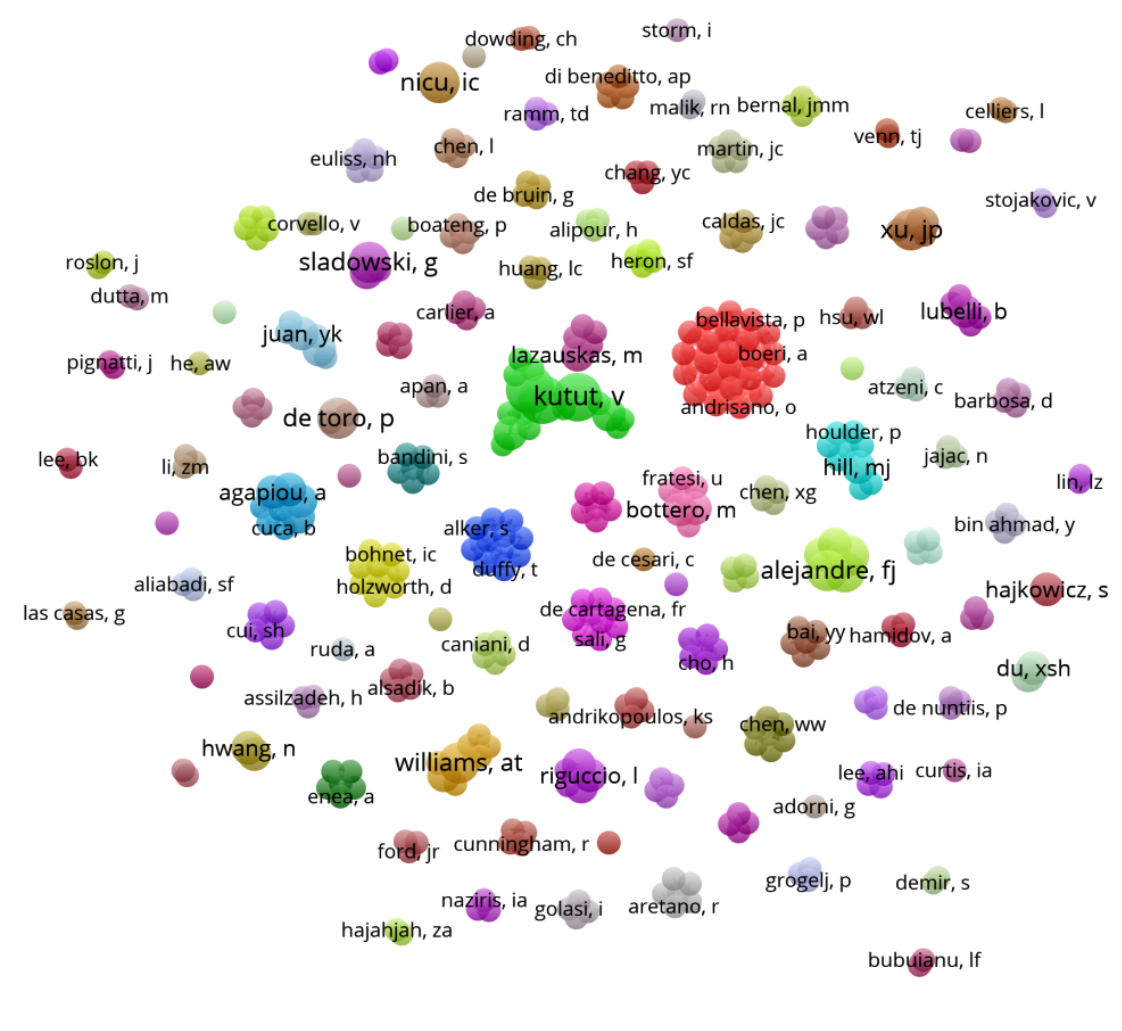

Figure 7. A map of MCDM methods application in cultural heritage buildings area according to authors (WoS, 11 November 2018) 
Table 4. Overview of MCDM methods application in cultural heritage buildings area according to authors

(WoS, 11 November 2018)

\begin{tabular}{|l|c|c|}
\hline \multicolumn{1}{|c|}{ Author } & Number of papers & Times cited \\
\hline Zavadskas, E. K. & 4 & 192 \\
\hline Turskis, Z. & 4 & 168 \\
\hline Kaklauskas, A. & 1 & 99 \\
\hline Seniut, M. & 1 & 99 \\
\hline Tupenaite, L. & 1 & 99 \\
\hline Kutut, V. & 4 & 82 \\
\hline Burinskiene, M. & 2 & 80 \\
\hline Curtis, I. A. & 1 & 71 \\
\hline Wang, H. J. & 2 & 66 \\
\hline Stenseke, M. & 1 & 63 \\
\hline Fernandes, L. F. S. & 1 & 56 \\
\hline Hajkowicz, S. A. & 1 & 56 \\
\hline Pacheco, F. A. L. & 1 & 56 \\
\hline Valle, R. F. & 1 & 56 \\
\hline Varandas, S. G. P. & 1 & 56 \\
\hline Hajkowicz, S. & 2 & 55 \\
\hline Zeng, Z. T. & 1 & 49 \\
\hline Williams, A. T. & 3 & 47 \\
\hline Xu, J. P. & 3 & 47 \\
\hline Hwang, N. & 2 & 45 \\
\hline Lee, M. G. & 2 & 42 \\
\hline Blumberga, A. & 1 & 42 \\
\hline Blumberga, D. & 1 & 42 \\
\hline Lazauskas, M. & & 42 \\
\hline Zagorskas, J. & 1 & 49 \\
\hline
\end{tabular}

number of citations per author, where the number of citations exceeds 35 , is presented. As can be seen, the five most cited authors are as follows: Zavadskas, E. K. (192), Turskis, Z. (168), Kaklauskas, A. (99), Seniut, M. (99) and Tupenaite, L. (99).

The citation analysis of papers is presented in Figure 8 and Table 5. In Figure 8, a map of the relevant papers on MCDM methods application in cultural heritage buildings area is presented. From the figure we can see the most relevant papers with bigger citation in the center of the map.

In Table 5, the most 25 cited papers in November 11, 2018 on MCDM methods application in cultural heritage buildings area excluding self-citation are presented. Of course, those values changes over time. And if we check the citation rates at another time, they will differ; since citation rates are dynamic by their nature and depend on the field of interest at some point in time. As can be seen from Table 5 column Total Citations (November 11, 2018) and Total Citations (January 8, 2019), values differs. Certainly, collecting values of those attributes for a certain period of time, it is possible to identify various trends, like real importance of particular papers. Now, the table shows the most popular papers for the moment of November 11, 2018.

\subsection{In-deep analysis of papers on MCDM methods application for cultural heritage buildings area}

A detailed analysis of papers, dealing with MCDM methods application for cultural heritage building's issues, is

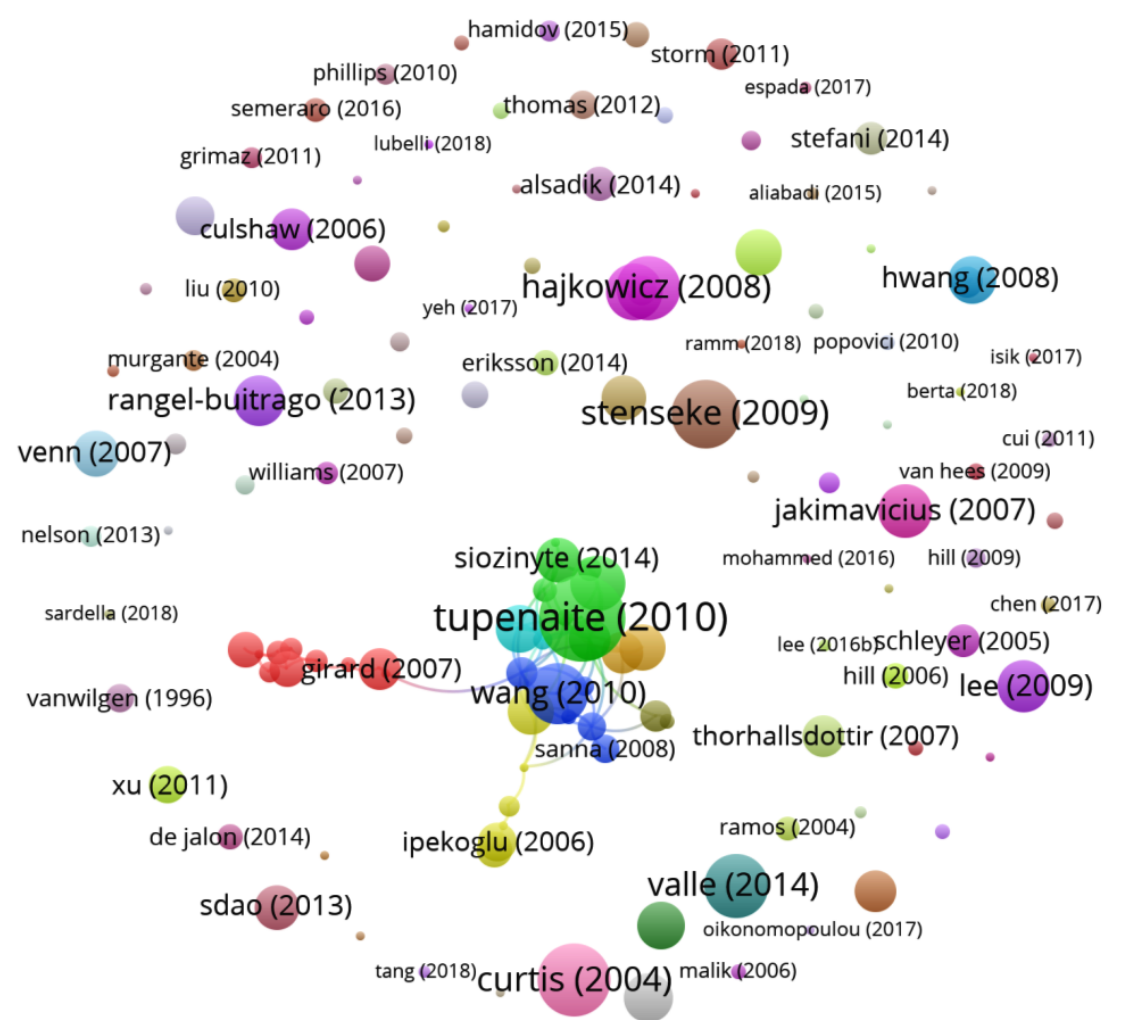

Figure 8. A map of papers on MCDM methods application in cultural heritage buildings area (WoS, 11 November 2018) 


\begin{tabular}{|c|c|c|c|c|c|c|c|c|c|c|c|c|c|c|c|c|c|c|c|c|c|c|c|c|}
\hline $8 \mathrm{~L} 0 \mathrm{Z}$ & 으 & $\wedge$ & $\circ$ & $\exists$ & $m$ & 6 & $m$ & $\infty$ & 0 & $\sim$ & $\psi$ & $H$ & $N$ & in & 6 & $m$ & in & $n$ & - & $m$ & $\sim$ & - & 0 & $\sim$ \\
\hline$\angle \mathrm{L} 0 \mathrm{Z}$ & $=$ & in & $m$ & 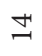 & $\sim$ & $\infty$ & 6 & $\stackrel{\infty}{=}$ & - & 6 & $\sim$ & 임 & in & 음 & $\sim$ & 6 & 6 & $\ltimes$ & 6 & $\infty$ & - & - & 0 & H \\
\hline $9 \mathrm{~L} 0 \mathrm{Z}$ & 6 & $\Rightarrow$ & $r$ & $\Xi$ & H & $\stackrel{2}{2}$ & $m$ & 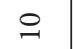 & 0 & $r$ & in & $\stackrel{2}{\sim}$ & N & in & 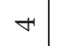 & $\wedge$ & $\wedge$ & $n$ & 0 & -1 & $m$ & $\wedge$ & + & - \\
\hline SI0Z & $a$ & $\infty$ & $\circ$ & $\stackrel{0}{\sim}$ & $n$ & $m$ & 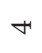 & 0 & $\rightarrow$ & $\wedge$ & $a$ & $\sim$ & $=$ & $\wedge$ & $\approx$ & $n$ & $\sigma$ & $H$ & $n$ & in & $\sim$ & in & - & - \\
\hline †I0Z & 0 & $H$ & $\stackrel{20}{-1}$ & - & H & 6 & $m$ & 0 & $\sim$ & $N$ & $\sim$ & 0 & - & - & $\sim$ & 6 & 0 & in & $m$ & $m$ & $m$ & - & + & $\sim$ \\
\hline$\varepsilon$ IL $0 z$ & $\infty$ & $\wedge$ & in & 0 & in & $\curvearrowright$ & $a$ & 0 & $\sim$ & $m$ & $a$ & 0 & $\wedge$ & 0 & $\sim$ & $m$ & 0 & $n$ & 0 & $\sim$ & 0 & - & - & $\sim$ \\
\hline ZIOZ & $\stackrel{\infty}{\sim}$ & $\wedge$ & in & 0 & in & $m$ & $m$ & 0 & - & $m$ & $\sim$ & 0 & $m$ & 0 & 0 & 0 & 0 & $\sim$ & 0 & 0 & $H$ & - & 0 & $\sim$ \\
\hline I I0Z & $\triangleq$ & $H$ & $\wedge$ & 0 & 음 & -7 & $m$ & 0 & $m$ & $r$ & 0 & 0 & 0 & 0 & 0 & 0 & 0 & 0 & 0 & 0 & 0 & - & $N$ & 0 \\
\hline $0 \mathrm{I} 0 \mathrm{Z}$ & 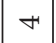 & $\infty$ & $\sim$ & 0 & $\simeq$ & 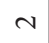 & 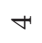 & 0 & $\Rightarrow$ & $m$ & 0 & 0 & 0 & 0 & 0 & 0 & 0 & 0 & 0 & -1 & 0 & 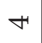 & - & $m$ \\
\hline $600 z$ & 0 & $r$ & $\sim$ & 0 & $m$ & 0 & $N$ & 0 & $\simeq$ & $N$ & 0 & 0 & 0 & 0 & 0 & 0 & 0 & 0 & 0 & 0 & $\sim$ & - & $\wedge$ & 0 \\
\hline $800 z$ & 0 & $m$ & 0 & 0 & - & 0 & $m$ & 0 & in & 0 & 0 & 0 & 0 & 0 & 0 & 0 & 0 & 0 & 0 & 0 & 0 & 0 & - & - \\
\hline$\angle 00 z$ & 0 & $\sim$ & 0 & 0 & 0 & 0 & 0 & 0 & 0 & 0 & 0 & 0 & 0 & 0 & 0 & 0 & 0 & 0 & 0 & 0 & 0 & 0 & $\sim$ & $\sim$ \\
\hline $900 z$ & 0 & 0 & 0 & 0 & 0 & 0 & 0 & 0 & 0 & 0 & 0 & 0 & 0 & 0 & 0 & 0 & 0 & 0 & 0 & 0 & 0 & 0 & 0 & - \\
\hline 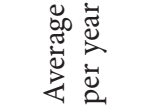 & $\exists$ & 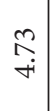 & $\tilde{\sigma}$ & $\stackrel{\text { I }}{=}$ & iे & $\underset{f}{f}$ & $\begin{array}{l}\infty \\
\stackrel{\infty}{n} \\
m\end{array}$ & $\underset{\infty}{+!}$ & $\vec{m}$ & $\stackrel{\circ}{\dot{m}}$ & $\stackrel{m}{\underset{+}{*}}$ & 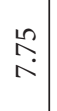 & 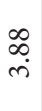 & $\dot{\varphi}$ & $\begin{array}{l}\hat{\sigma} \\
\stackrel{+}{+}\end{array}$ & $\begin{array}{c}\hat{b} \\
\stackrel{+}{+}\end{array}$ & $\stackrel{\ddot{n}}{\ddot{n}}$ & $m$ & $\begin{array}{c}\infty \\
\dot{m} \\
\dot{m}\end{array}$ & $\stackrel{m}{i}$ & $\underset{-}{\sigma}$ & 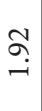 & 今ે & $\stackrel{\sim}{\widetilde{T}}$ \\
\hline 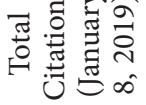 & 2 & 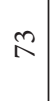 & 6 & हो & $\stackrel{\infty}{n}$ & Fे & $\stackrel{m}{f}$ & F & $\stackrel{\infty}{m}$ & $\stackrel{\infty}{m}$ & $\hat{m}$ & $\tilde{m}$ & ल & ㅇ. & $\stackrel{\infty}{\sim}$ & $\stackrel{\infty}{\sim}$ & $\stackrel{\infty}{\sim}$ & $\widehat{\lambda}$ & $\tilde{\lambda}$ & $\ddot{\sim}$ & $\stackrel{\vec{N}}{\sim}$ & $\tilde{\sim}$ & $\stackrel{\sharp}{\sim}$ & $\vec{\sim}$ \\
\hline 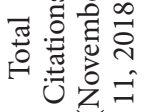 & 2 & $\pi$ & 8 & i̊ & $\stackrel{\circ}{\circ}$ & के & $\stackrel{m}{F}$ & F & $\stackrel{\infty}{\infty}$ & $\stackrel{\infty}{\infty}$ & $\tilde{m}$ & $\vec{m}$ & $\vec{m}$ & $\stackrel{\infty}{\sim}$ & $\stackrel{\infty}{\sim}$ & $\stackrel{\infty}{\sim}$ & $\widehat{\curvearrowright}$ & $\widehat{\sim}$ & $\tilde{\imath}$ & $\tilde{\sim}$ & $\ddot{\sim}$ & $\ddot{\sim}$ & $\tilde{\sim}$ & $\vec{\sim}$ \\
\hline 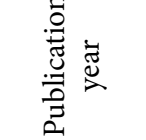 & 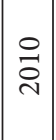 & $\begin{array}{l}+⿱ 艹 \\
\text { ¿े } \\
\text {. }\end{array}$ & ڤેे & $\underset{\sim}{\stackrel{\sim}{*}}$ & 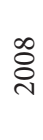 & $\stackrel{\circ}{\stackrel{2}{\sim}}$ & 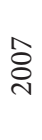 & $\underset{\sim}{\stackrel{2}{\sim}}$ & 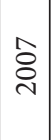 & ڤ્ণે & $\vec{\nabla}$ & $\begin{array}{l}\stackrel{n}{\sim} \\
\stackrel{\sim}{\sim}\end{array}$ & $\overrightarrow{\vec{\sim}}$ & $\begin{array}{l}\overrightarrow{1} \\
\vec{\sim}\end{array}$ & $\begin{array}{l}m \\
\vec{\sim}\end{array}$ & $\begin{array}{l}m \\
\stackrel{\sim}{\sim}\end{array}$ & $\vec{d}$ & $\begin{array}{l}\stackrel{0}{\vec{\nu}} \\
\stackrel{\sim}{1}\end{array}$ & $\stackrel{m}{\stackrel{\sim}{\sim}}$ & ڤે & 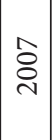 & ڤ્ণ & & ঃి \\
\hline 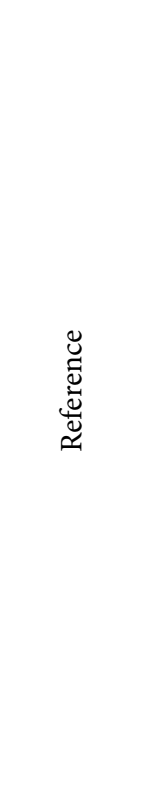 & 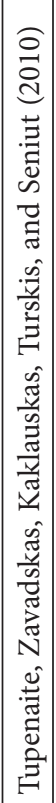 & 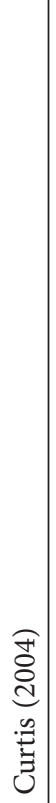 & 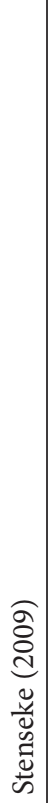 & 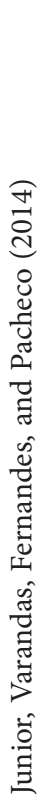 & 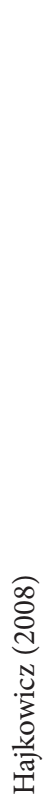 & 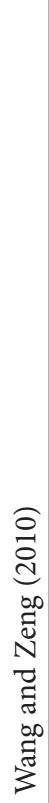 & 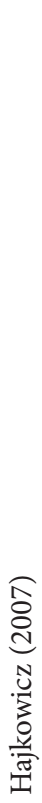 & 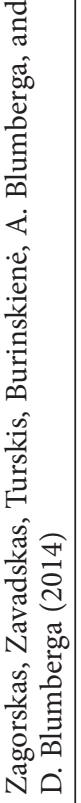 & 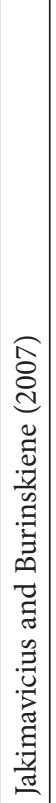 & 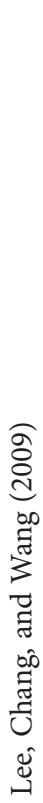 & 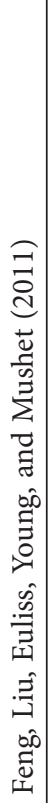 & 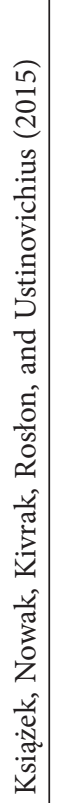 & 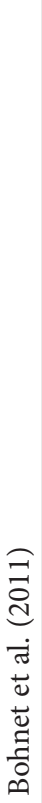 & 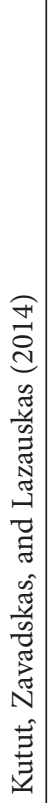 & 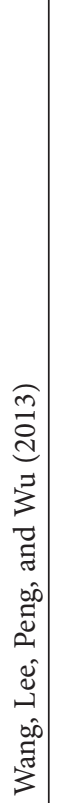 & 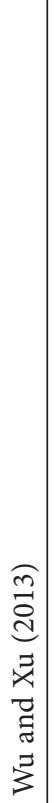 & 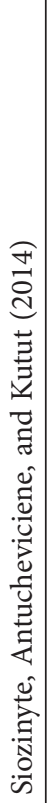 & 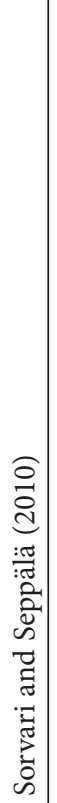 & 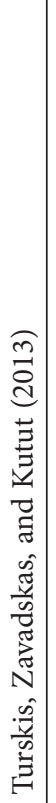 & 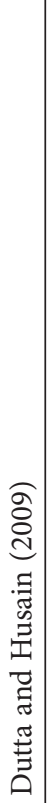 & 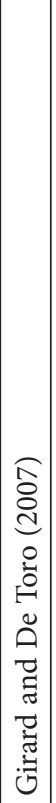 & 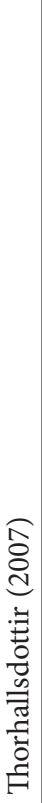 & 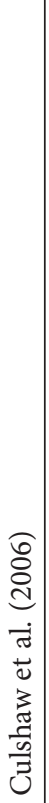 & 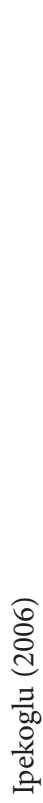 \\
\hline
\end{tabular}




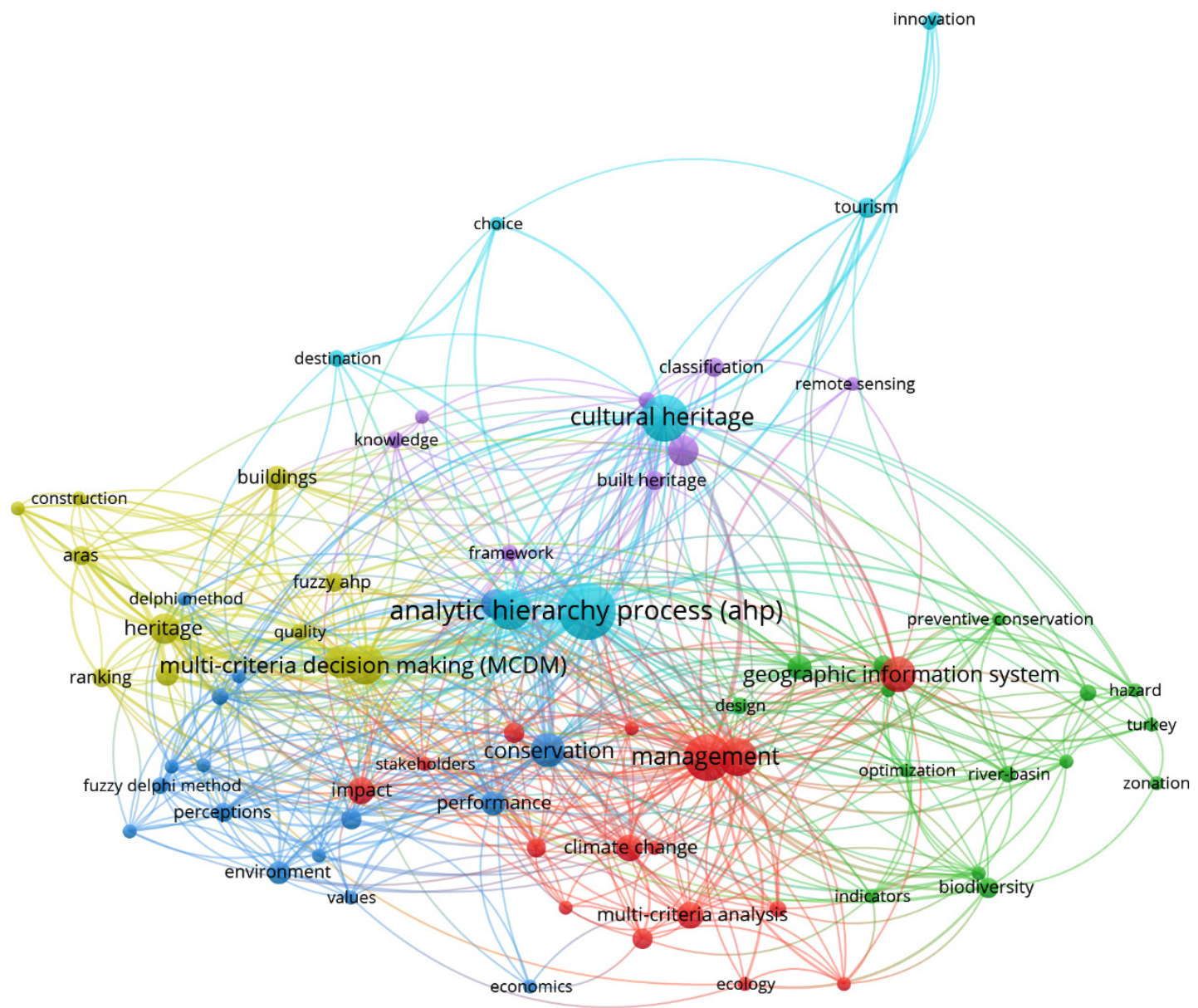

Figure 9. A map of keywords on MCDM methods application in cultural heritage buildings area

(WoS, 11 November 2018)

presented here. According to the obtained bibliometric data, a map of keywords is created using VOSviewer and presented in Figure 9.

A keywords map was generated using authors' and WoS presented keywords. As a result, 1226 keywords were detected. And applying VOSviewer algorithms the result 102 keywords, with minimum number of occurrences equals to 3 , is obtained. However, a received set of keywords should be refined one more time, since VOSviewer understands synonyms and same words with different orthography, like "modelling" and "modeling", "climate change" and "climate-change", etc., as different keywords. Therefore, the map created by VOSviewer was transferred to Gephi for the refinement of the primary set of keywords. In Gephi, similar terms (like "multi criteria decision making" and "MCDM", "AHP" and "analytic hierarchy process") were merged. A final map of keywords consists of 74 nodes (see Figure 9). It illustrates the main general areas of research determined in MCDM methods application in cultural heritage buildings area. Keywords with bigger number of occurrences are presented by bigger labels and they present main interests areas.

According to the in-deep analysis of a keywords map and keywords occurrences, the mostly used MCDM meth- ods, their number of occurrences, average publication year and average citations are presented in Table 6 . It can be seen from the table that the selected MCDM methods have been widely used in the period of 2014-2017.

According to the in-deep analysis of a keywords map and keywords occurrences, the mostly used places, where cultural heritage buildings have been assessed by a particular MCDM method, their number of occurrences, average publication year and average citations are presented in Table 7.

For the future in-deep analysis 52 papers (see Table 9) was selected by reading abstracts and full text of papers and eliminating inappropriate papers that contain relevant keywords, but don't fit the analyzed topic. In Table 9, we have presented an in-deep analysis of the selected 52 papers according to used MCDM method, main topic of the paper, and criteria used for the evaluation of alternatives.

The summary of the results of the used MCDM methods in 52 selected papers are presented in Table 9. As can be seen from the table, the three most used MCDM methods are AHP, ANP and fuzzy Delphi. Experts' evaluation is also popular. In 18 analyzed papers other MCDM methods are used, sometimes authors do not name them. Moreover, in 31 of analyzed papers a combination of several MCDM methods, like PROMETHEE and AHP, is used. 
Table 6. The mostly used MCDM methods in cultural heritage topic

\begin{tabular}{|l|c|c|c|}
\hline \multicolumn{1}{|c|}{ MCDM method } & weight<occurrences> & score<avg._pub._year> & score<avg._citations> \\
\hline Analytic hierarchy process (AHP) & 44 & 2016.0167 & 7.49706 \\
\hline Fuzzy Logic & 13 & 2013.3846 & 6.0769 \\
\hline ARAS & 5 & 2016.6 & 8.4 \\
\hline Fuzzy AHP & 5 & 2016.4 & 20.75 \\
\hline Analytic network process & 4 & 2013.5 & 19.25 \\
\hline Fuzzy Delphi method & 4 & 2014.75 & 18.3333 \\
\hline Delphi method & 3 & 2014 & 7 \\
\hline
\end{tabular}

Table 7. The mostly used places for the assessment

\begin{tabular}{|l|c|c|c|}
\hline \multicolumn{1}{|c|}{ MCDM method } & weight<occurrences $>$ & score<avg._pub._year $>$ & score<avg._citations $>$ \\
\hline China & 6 & 2015.1667 & 6.5 \\
\hline Hong-Kong & 3 & 2017.6667 & 0.3333 \\
\hline Turkey & 3 & 2015 & 15.3333 \\
\hline
\end{tabular}

The in-deep analysis of assessment criteria shows that cultural heritage buildings are evaluated by different aspects as follows Historical value, Artistic value, Technological value, Social value, Economic value, Location and accessibility.

\section{Discussion}

Heritage buildings are an important part of social, economic, historical, architectural and cultural identity of numerous countries. Cultural heritage buildings indicate spiritual, cultural, archaeological, historical, ethnic, social, economic and technological value, conveyed over time. Considering to invaluable values of heritage buildings, the scientists and government are trying to find the best possibilities for heritage buildings preservation and conservation.

Although, MCDM methods are widely used in different areas to choose an objective solution from possible, till now MCDM methods application in cultural heritage buildings area is weak. This can be stated by the small number of papers found in this area. The main topics of usage of MCDM in cultural heritage buildings are as follows: selecting appropriate reuse alternative, selecting appropriate refurbishment alternative, selecting suitable alternatives for refurbishment projects, determining level of hazards. The most used MCDM methods are as follows: AHP and fuzzy AHP, Delphi and fuzzy Delphi. Experts' knowledge is also used for the assessment of cultural heritage value and to select an optimal alternative for its conservation or refurbishment. Another popular approach in assessing cultural heritage value is using fuzzy analysis. Combination of several MCDM methods is useful in applying complex problem solving in cultural heritage buildings area.
However, as was obtained from the results of primary and in-deep analysis, there is luck of approaches on applying MCDM in cultural heritage buildings area. Moreover, existing researches and approaches are not interrelated. There is paid not enough attention for complex evaluation of cultural heritage buildings as in separate countries and regions as in global perspective. Existing researches and approaches are not interconnected and are not interrelated.

\section{Conclusions}

The analysis of papers on MCDM methods application in cultural heritage buildings area shows that, although, MCDM methods are widely used in many other areas, their usage in the field of cultural heritage buildings is weak.

As a primary analysis with bibliometric data visualization of the relevant papers shows, the three most popular WoS Categories are Environmental Sciences (32), Geosciences Multidisciplinary (30) and Environmental Study (26). The main three countries, working in the analyzed topic, are Italy (29), Australia (19) and China (18). However, the priorities of countries according to the citation are as follows: Lithuania (314), Australia (288) and Italy (153). The main three organizations, working on the analyzed topic, are Vilnius Gediminas Tech Univ (Lithuania) (9), Chinese Acad Sci (China) (7) and Univ Seville (Spain) (5). The three most cited authors are Zavadskas, E. K. (192), Turskis, Z. (168) and Kaklauskas, A. (99).

Considering that applications on topic of "heritage building" and "historic building" have been published more than 1039 journal papers in English, the use of MCDM methods to deal with heritage buildings consisted only $17 \%$ of total number. The biggest part of papers was published in 2016. 


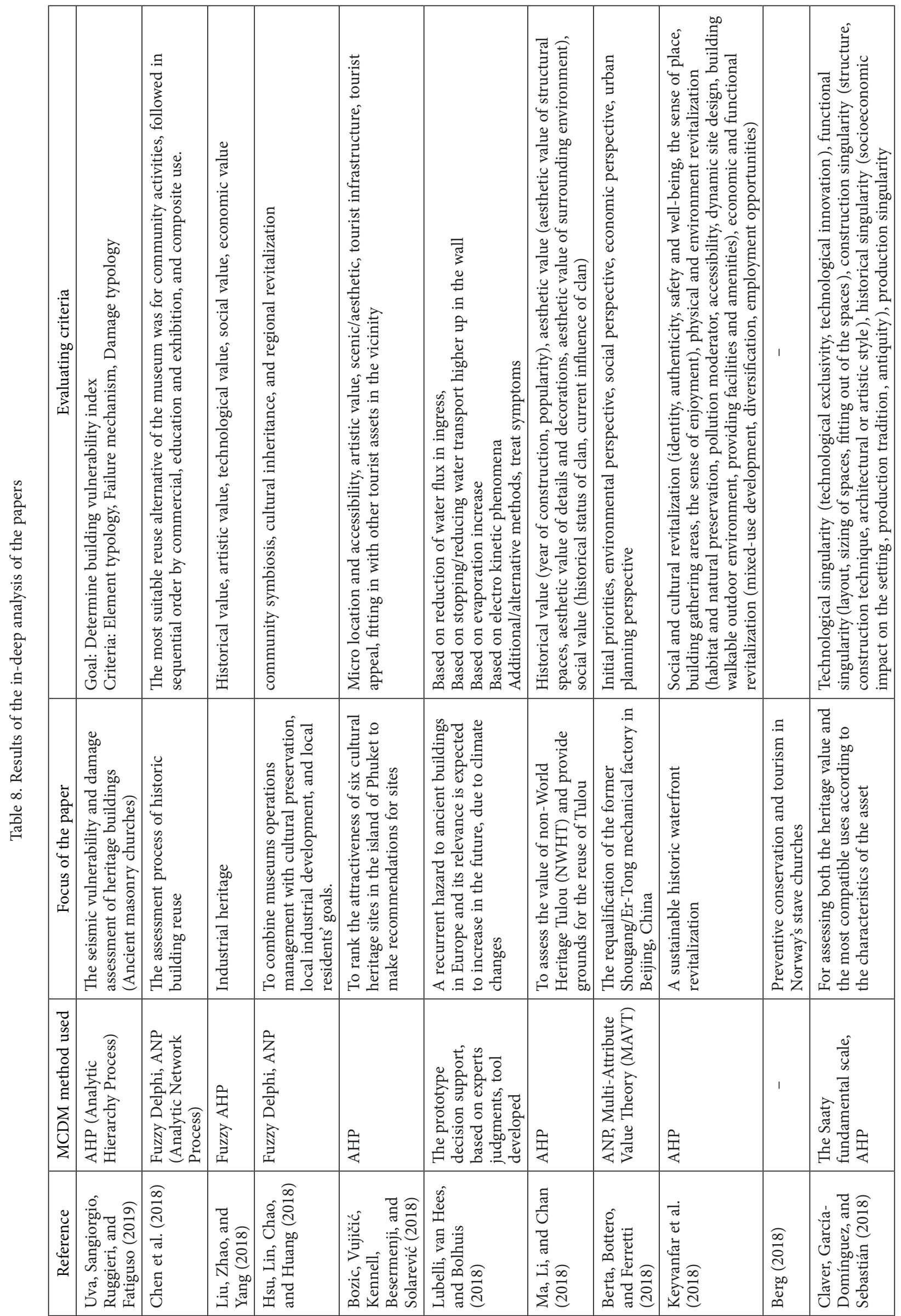




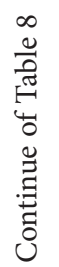

\begin{tabular}{|c|c|c|c|c|c|c|c|c|c|c|}
\hline I & 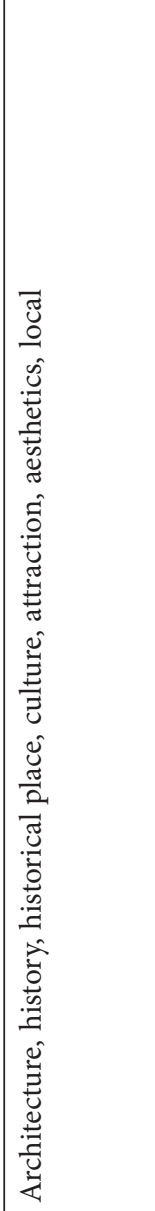 & 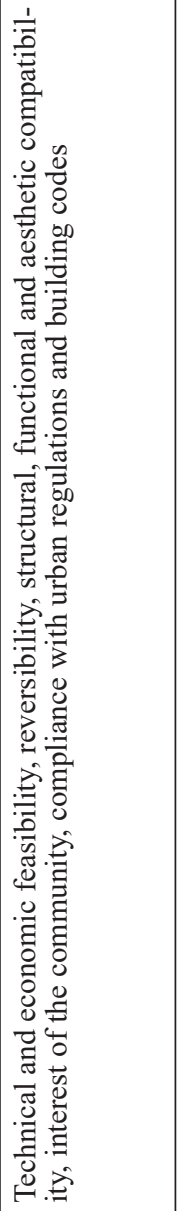 & 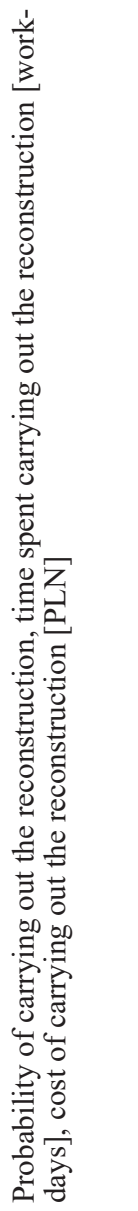 & 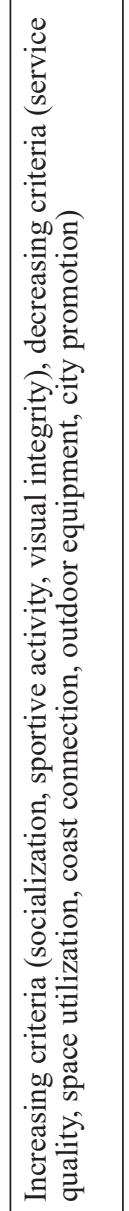 & 1 & 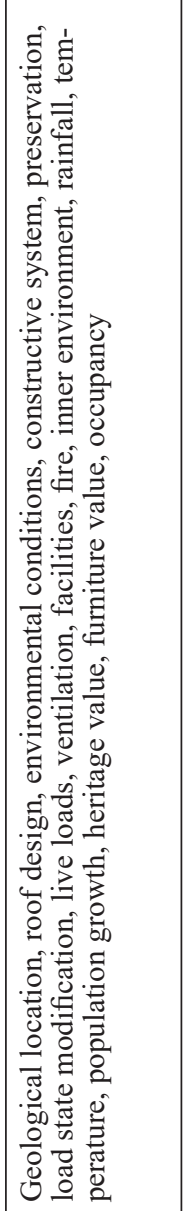 & 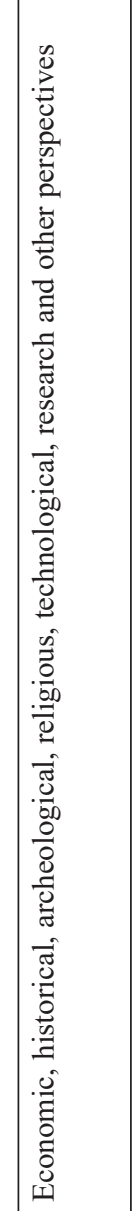 & 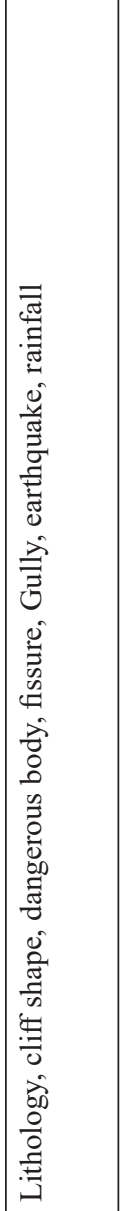 & 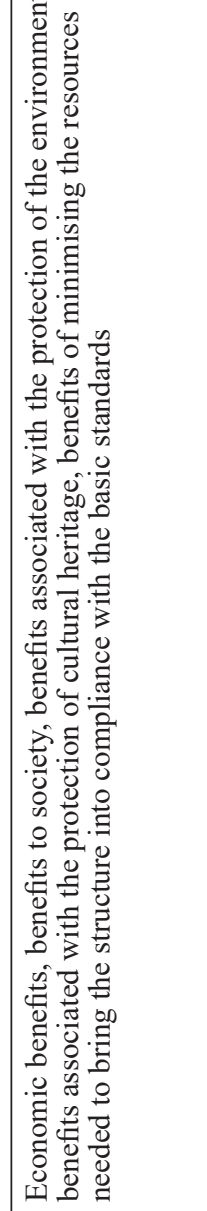 & 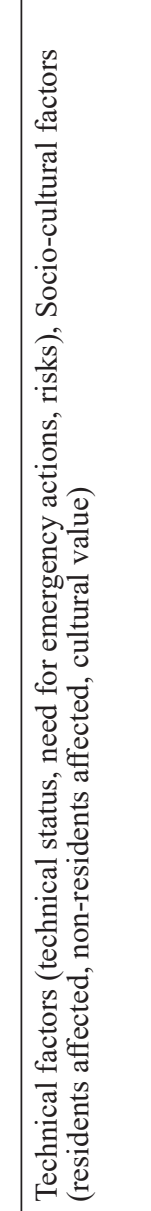 \\
\hline & 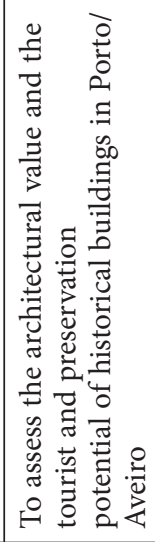 & 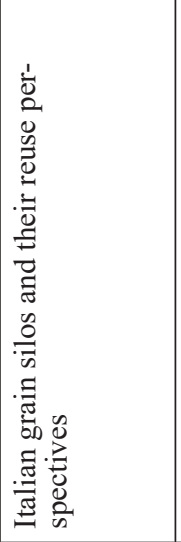 & 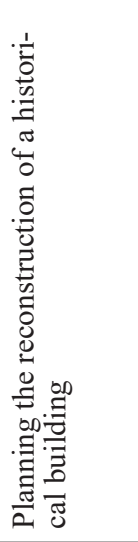 & 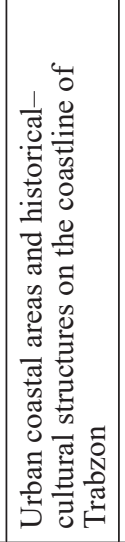 & 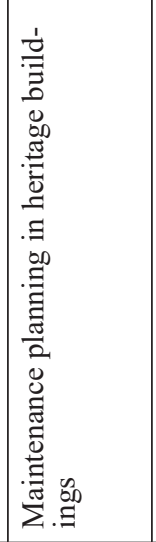 & 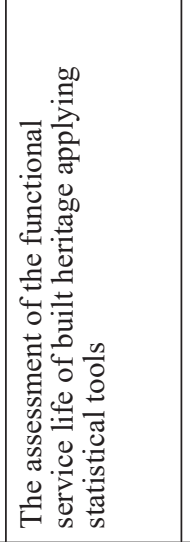 & 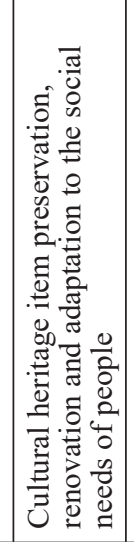 & 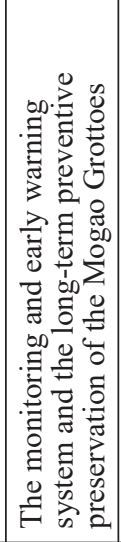 & 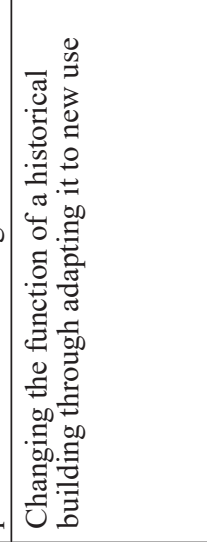 & 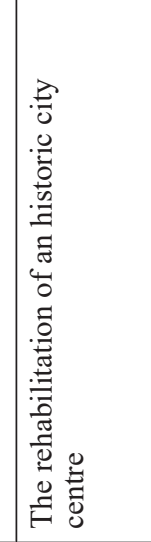 \\
\hline & 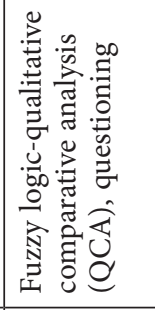 & 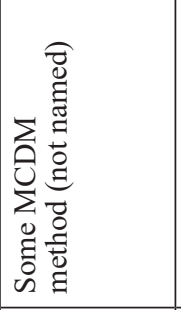 & 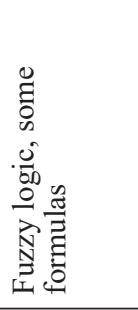 & 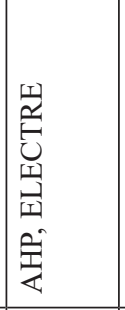 & 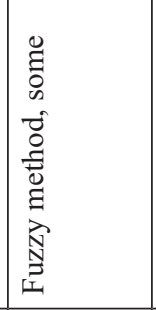 & 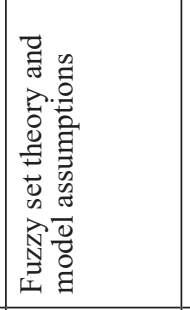 & 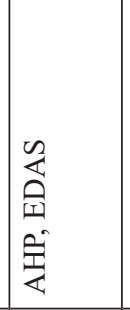 & 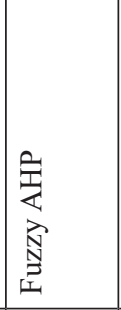 & 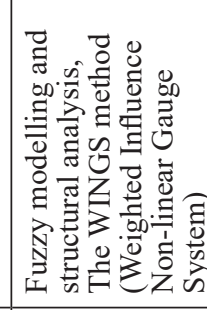 & $\frac{1}{4}$ \\
\hline & 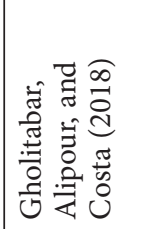 & 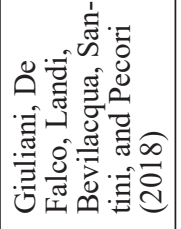 & 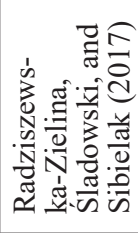 & 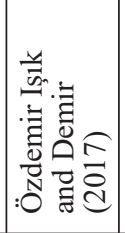 & 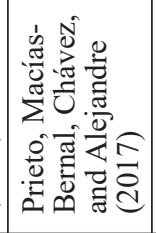 & 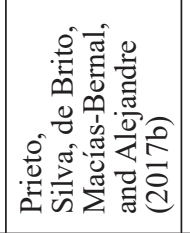 & 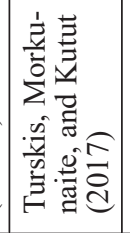 & 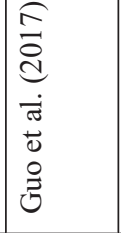 & 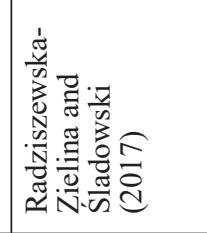 & 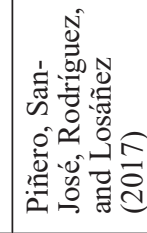 \\
\hline
\end{tabular}




\begin{tabular}{|c|c|c|c|c|c|c|c|c|c|}
\hline & 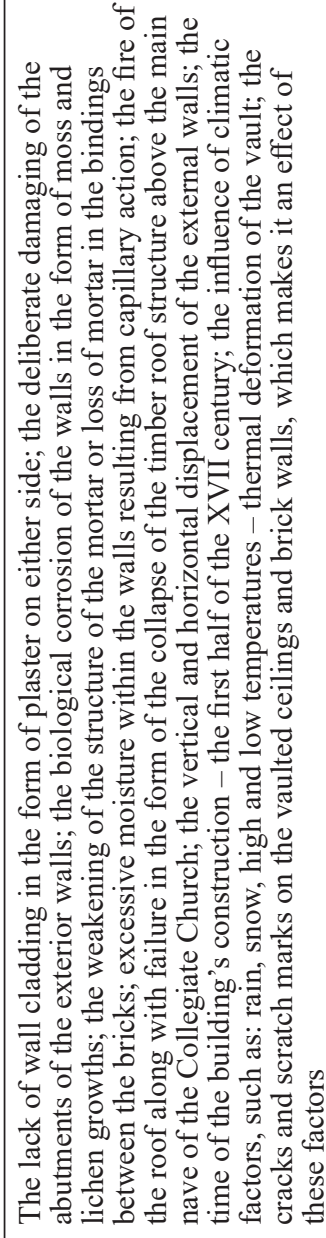 & 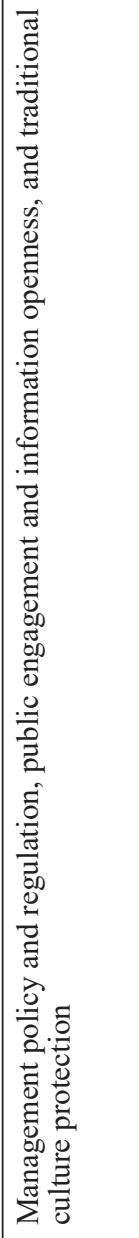 & 1 & 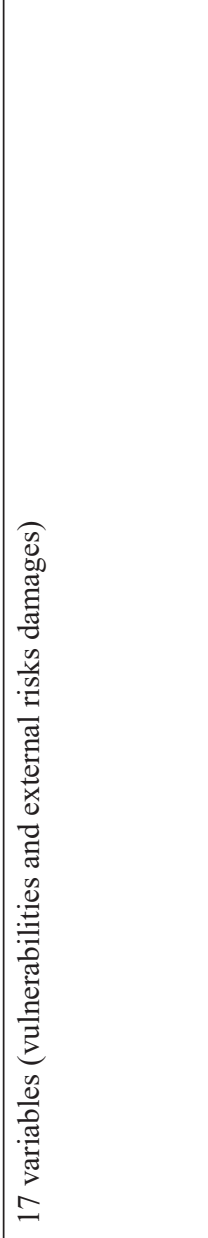 & 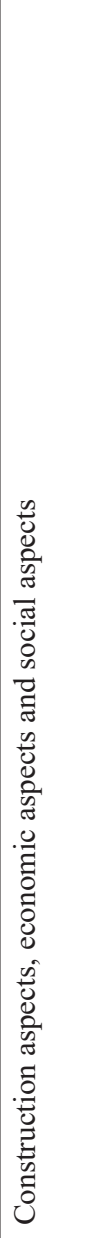 & 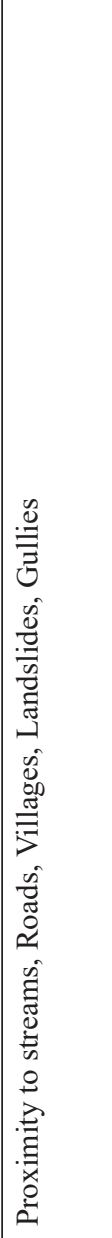 & 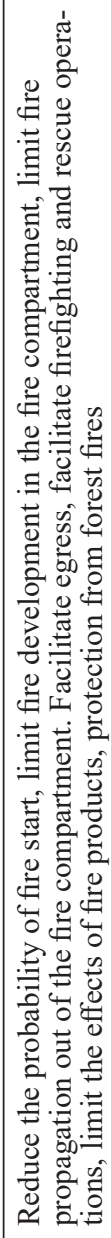 & 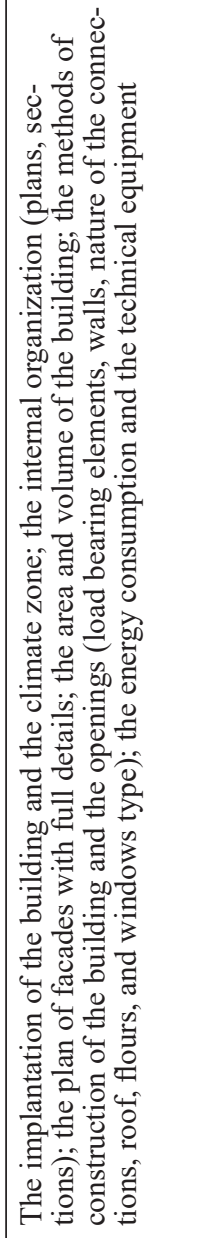 & 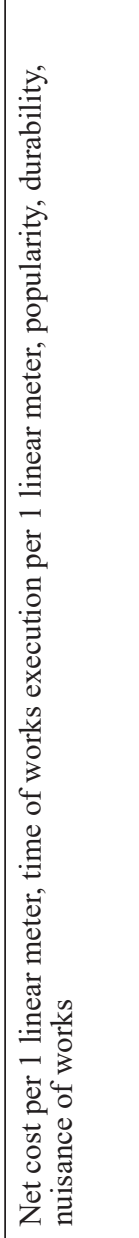 \\
\hline 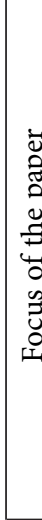 & 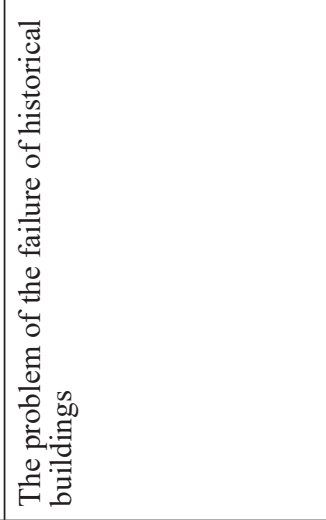 & 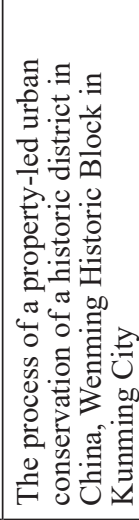 & 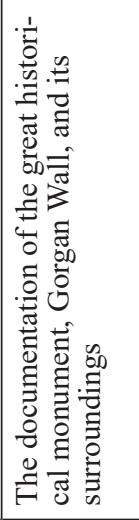 & 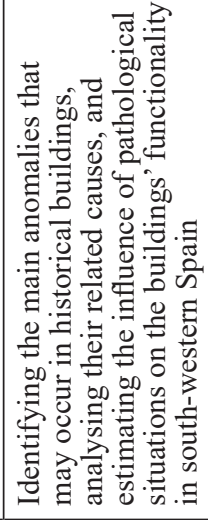 & 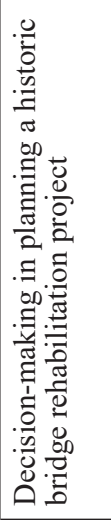 & 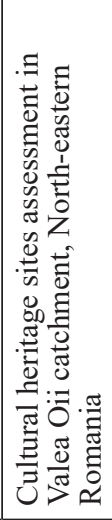 & 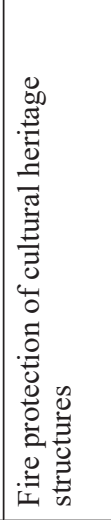 & 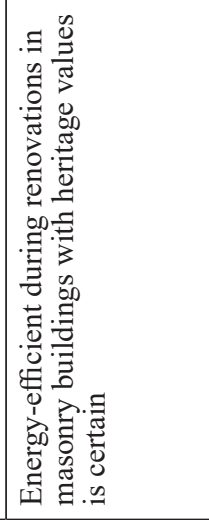 & 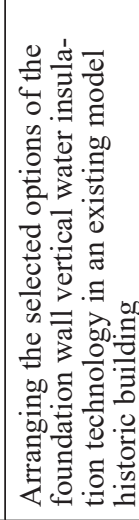 \\
\hline 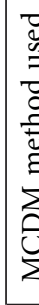 & 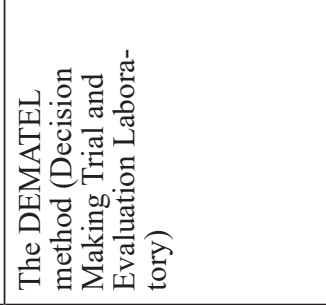 & 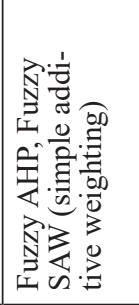 & 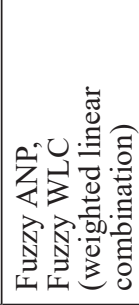 & 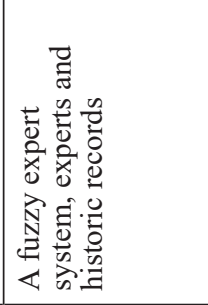 & 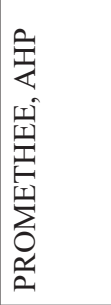 & 至 & 吾 & 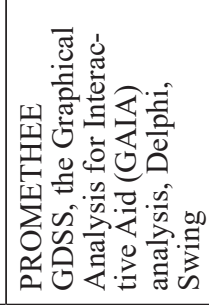 & 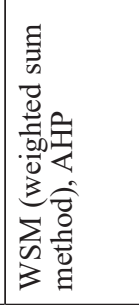 \\
\hline 9 & 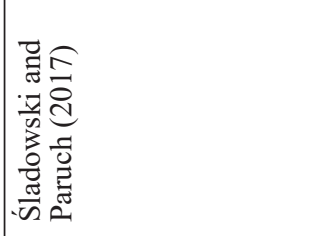 & 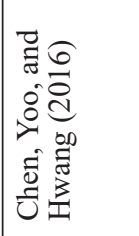 & 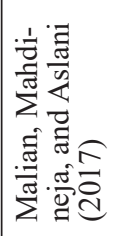 & 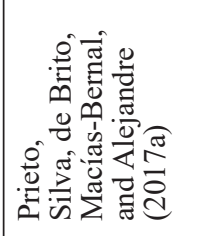 & 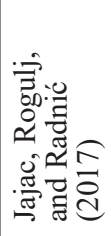 & $\begin{array}{l}0 \\
0 \\
0 \\
d \\
z \\
0 \\
z \\
z\end{array}$ & 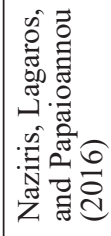 & 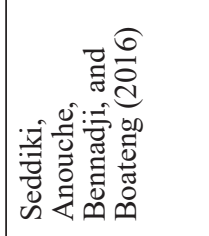 & 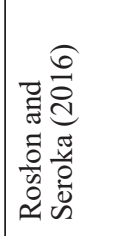 \\
\hline
\end{tabular}




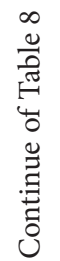

\begin{tabular}{|c|c|c|c|c|c|c|c|}
\hline & I & 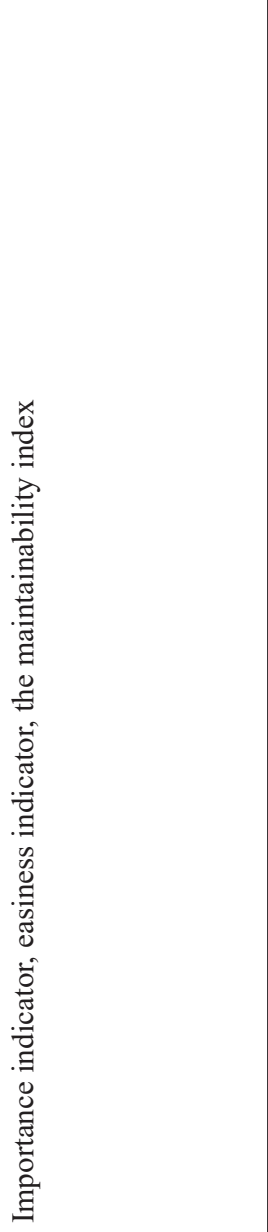 & 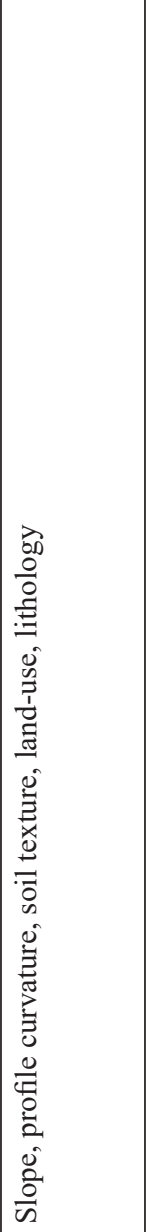 & 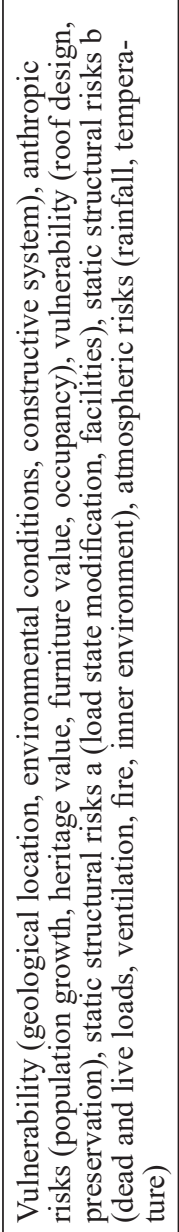 & 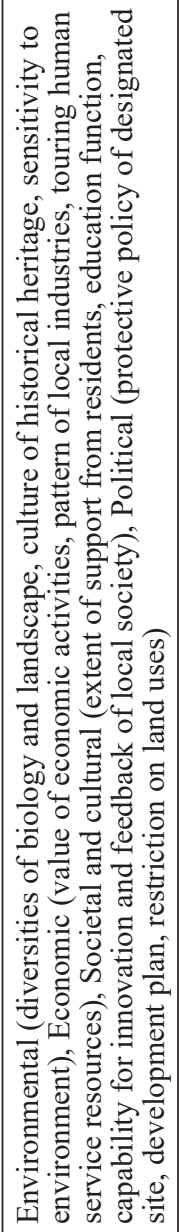 & 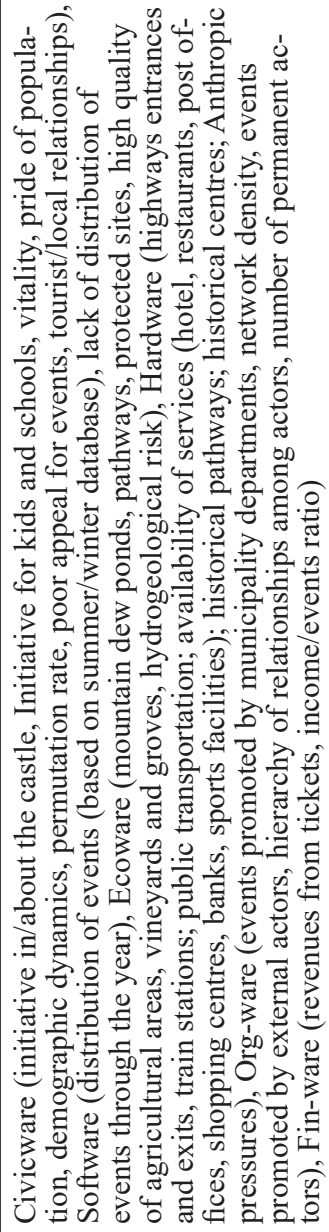 & 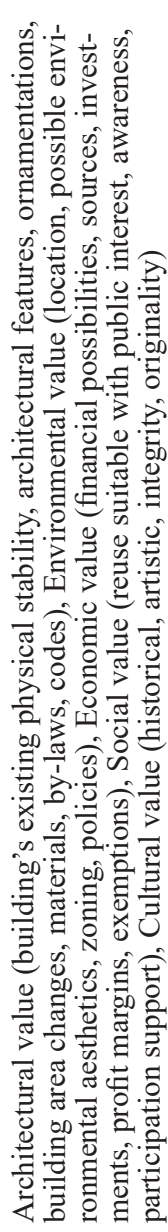 \\
\hline 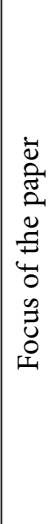 & 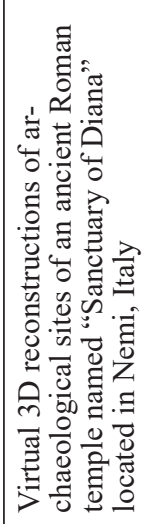 & 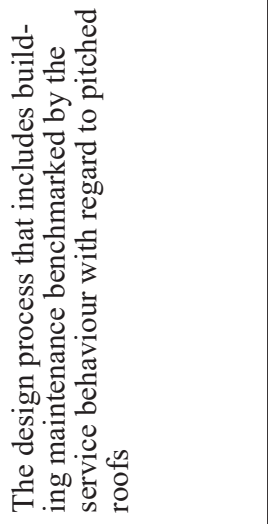 & 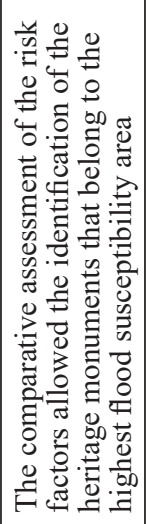 & 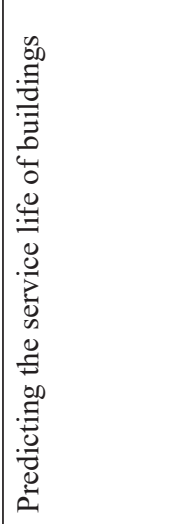 & 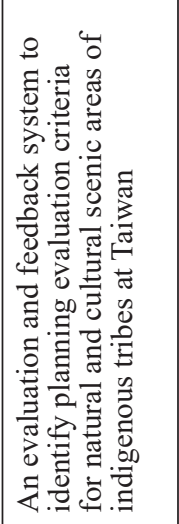 & 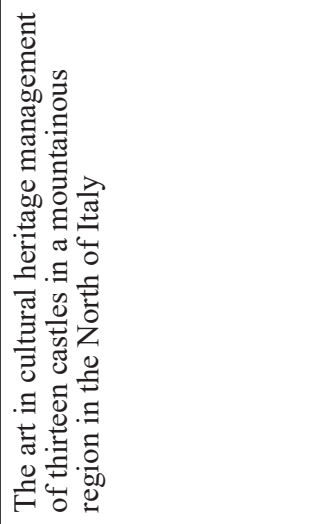 & 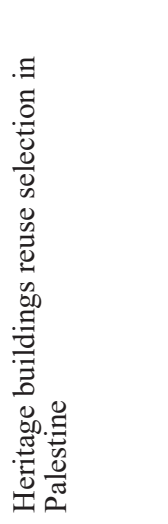 \\
\hline 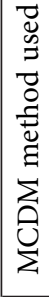 & 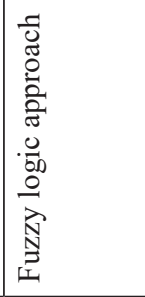 & 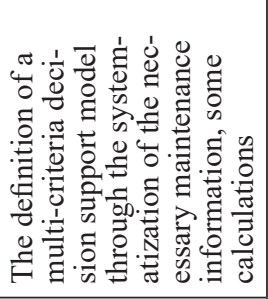 & 王 & 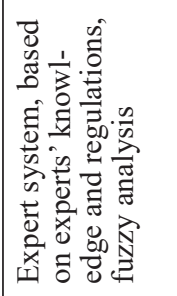 & 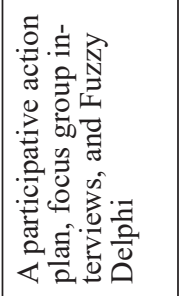 & 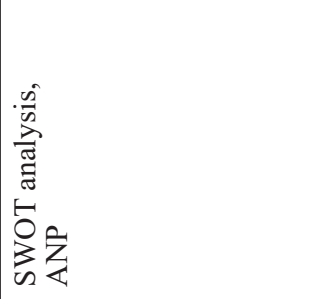 & 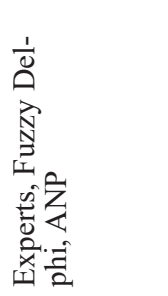 \\
\hline 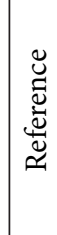 & 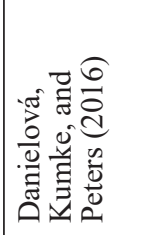 & 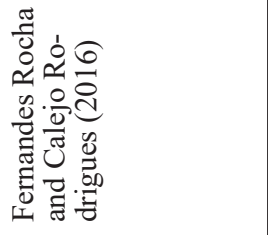 & 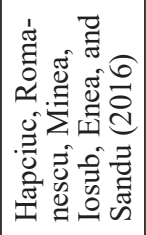 & 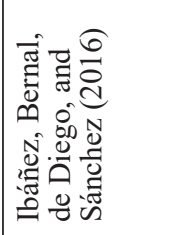 & 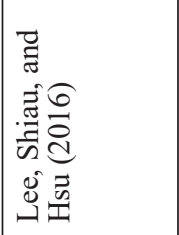 & 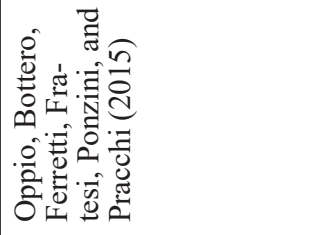 & 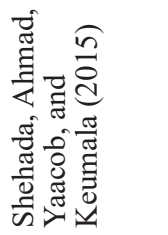 \\
\hline
\end{tabular}




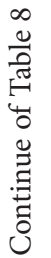

\begin{tabular}{|c|c|c|c|c|c|c|c|c|}
\hline 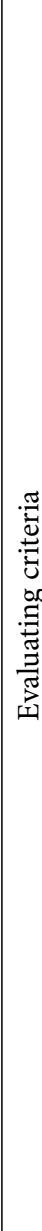 & 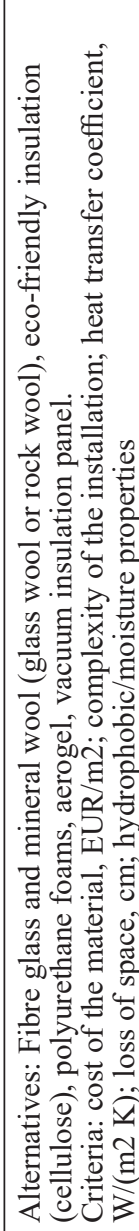 & 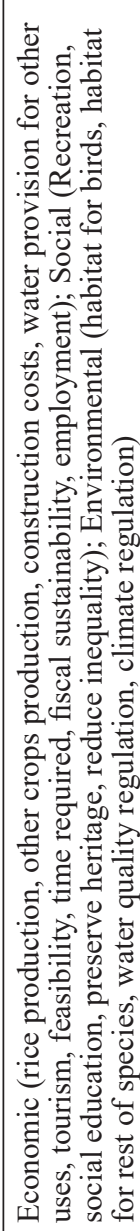 & 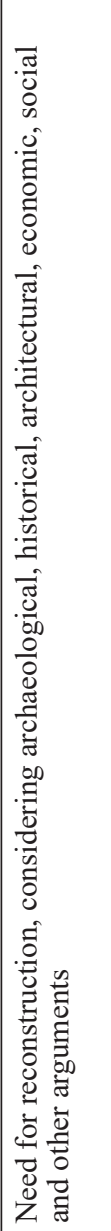 & 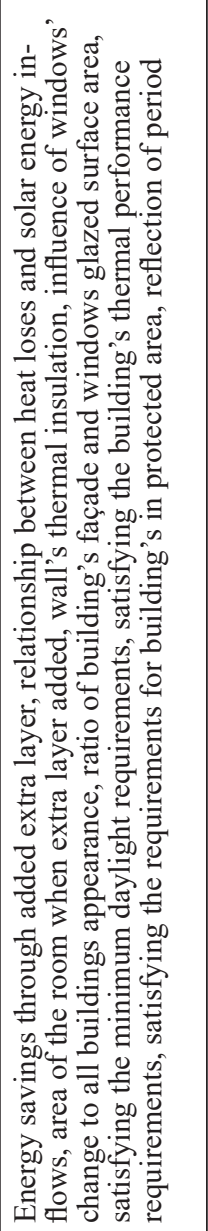 & 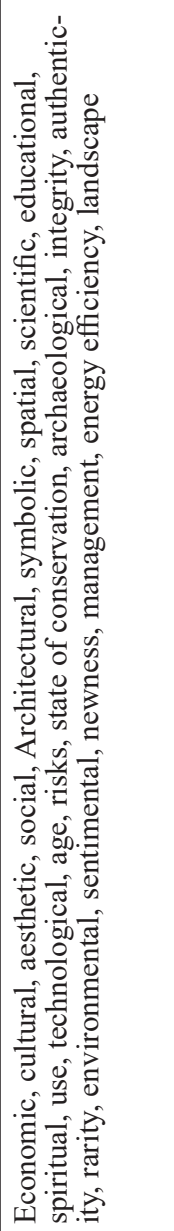 & 1 & 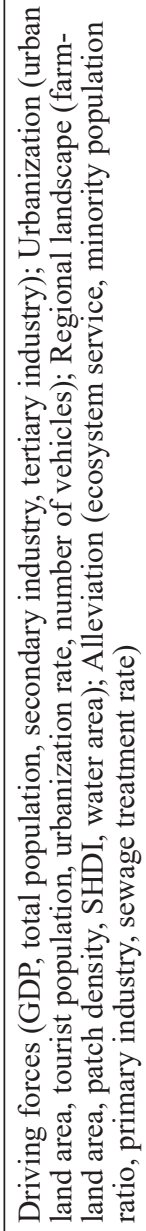 & 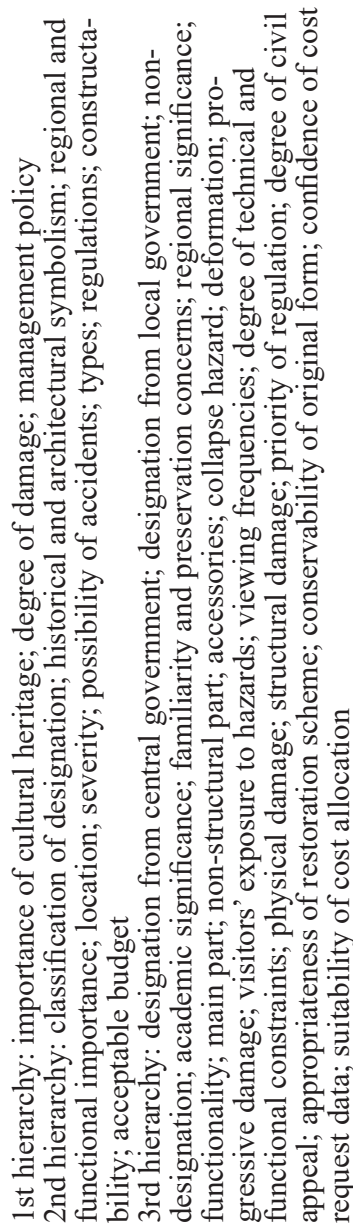 \\
\hline & 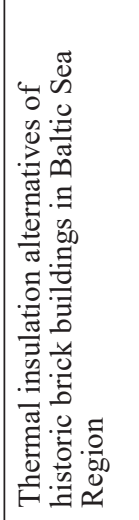 & 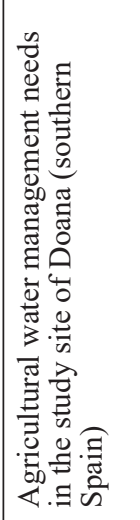 & 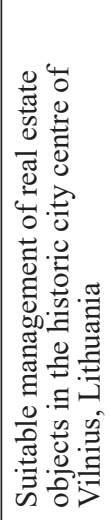 & 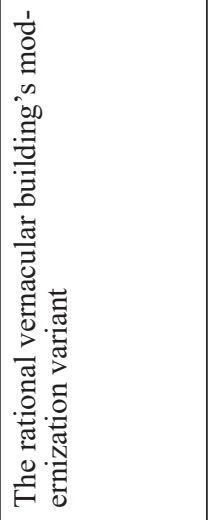 & 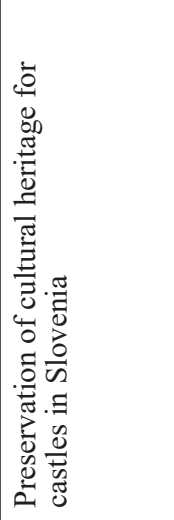 & 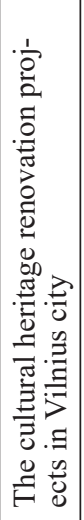 & 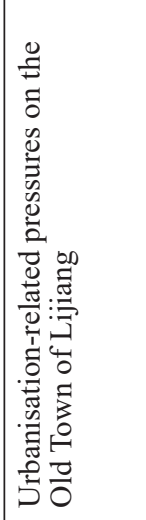 & 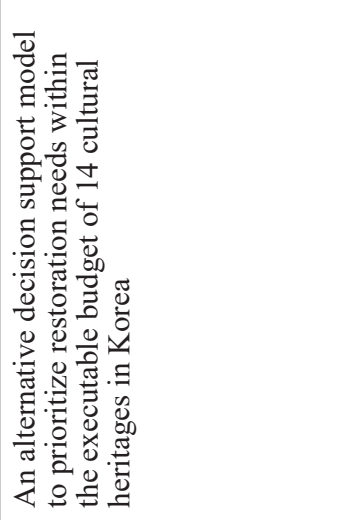 \\
\hline 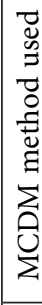 & $\begin{array}{l}\text { n } \\
\text { n } \\
0 \\
0 \\
0\end{array}$ & 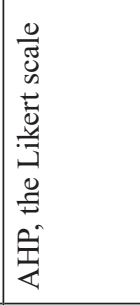 & 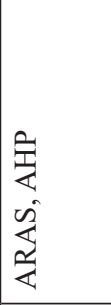 & 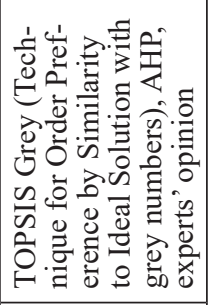 & $\frac{\pi}{4}$ & 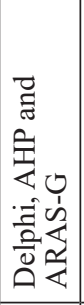 & 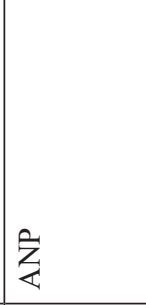 & 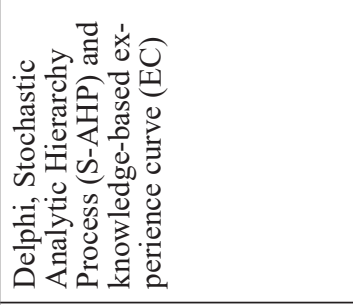 \\
\hline 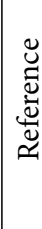 & 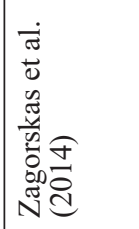 & 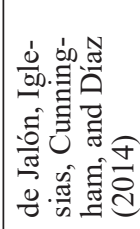 & 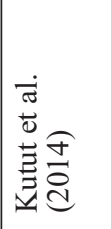 & 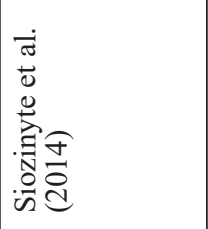 & 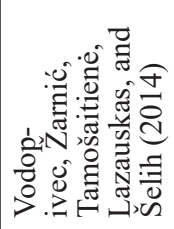 & 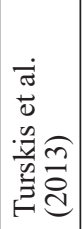 & 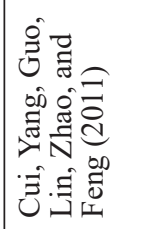 & 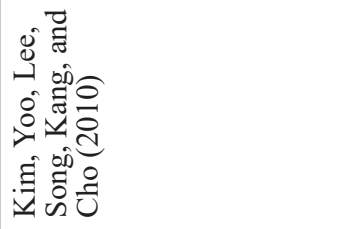 \\
\hline
\end{tabular}




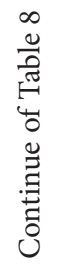

\begin{tabular}{|c|c|c|c|c|c|c|c|}
\hline 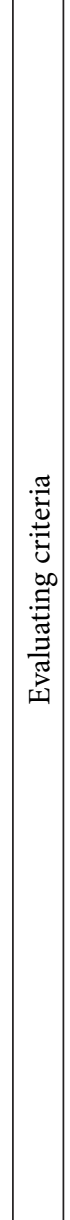 & 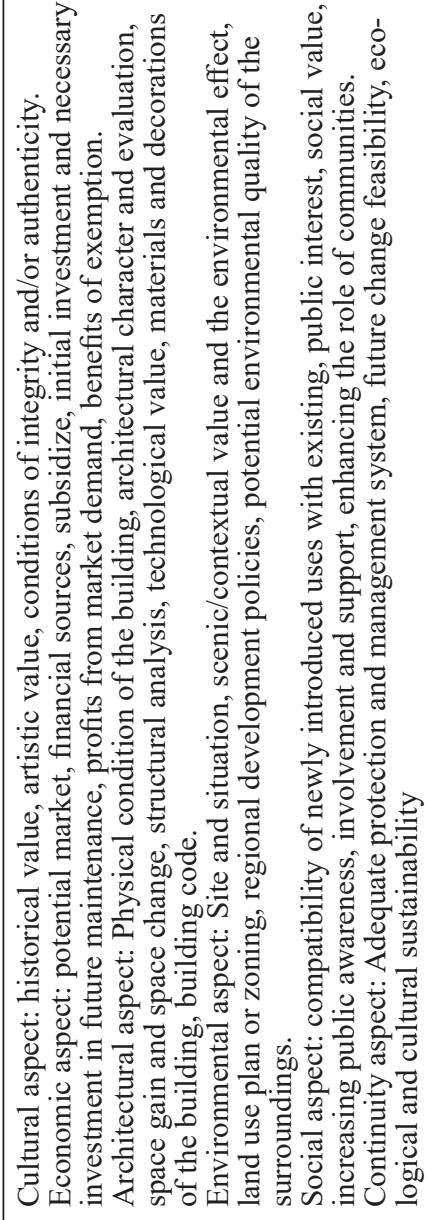 & 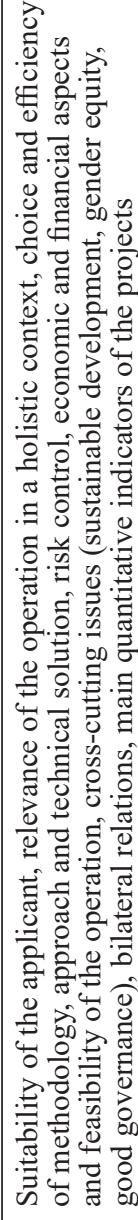 & 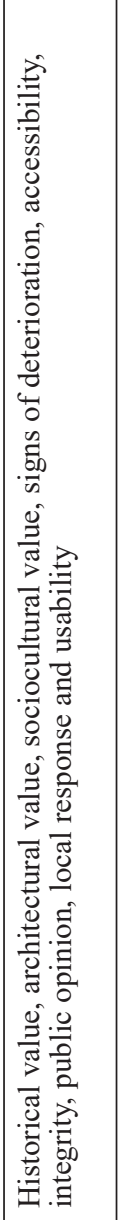 & 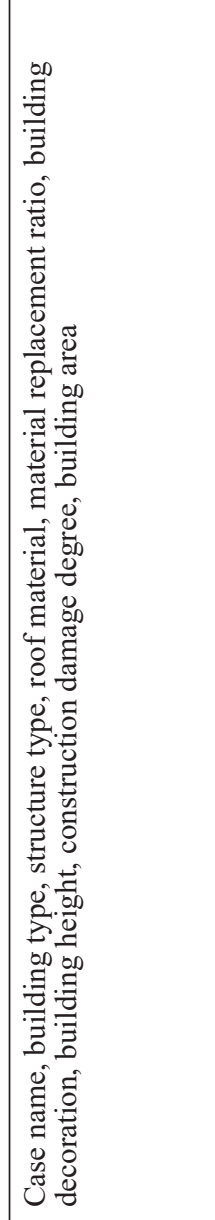 & 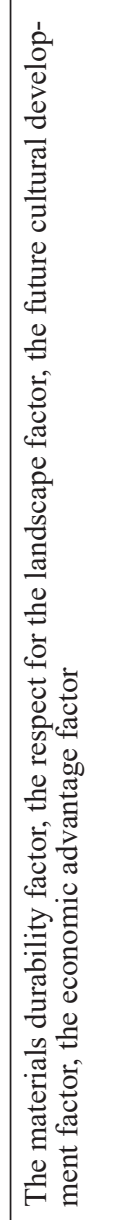 & 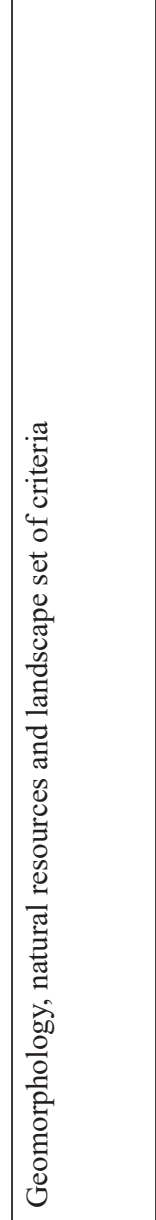 & \\
\hline 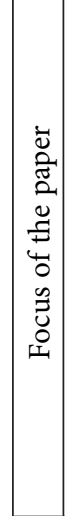 & 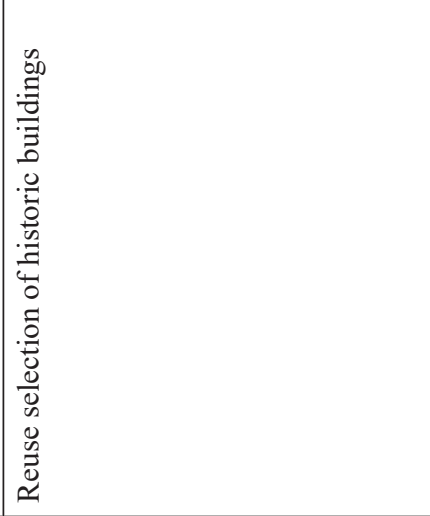 & 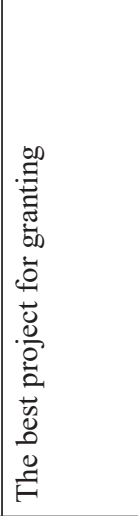 & 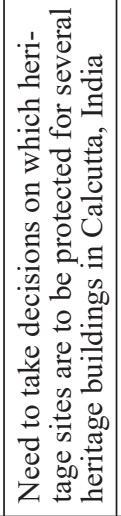 & 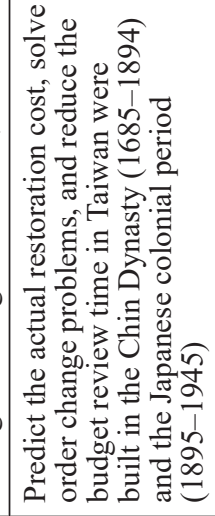 & 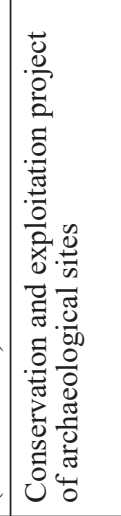 & 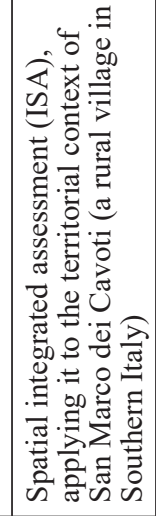 & 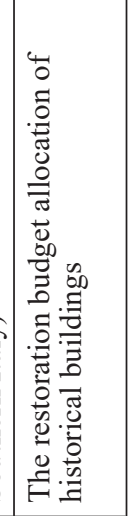 \\
\hline 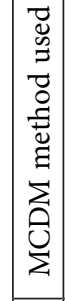 & $\mid \begin{array}{l}2 \\
2 \\
3 \\
\overline{3} \\
\overline{3} \\
0 \\
0\end{array}$ & 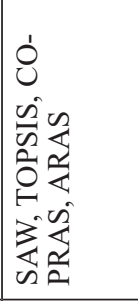 & 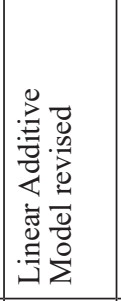 & 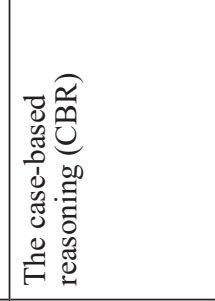 & 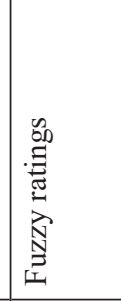 & 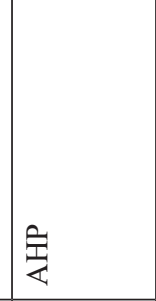 & 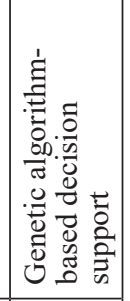 \\
\hline & 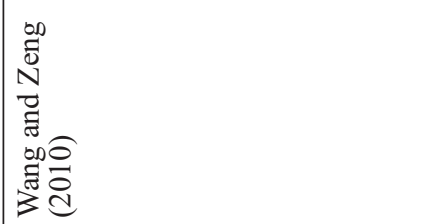 & 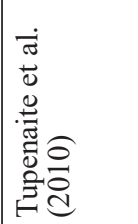 & 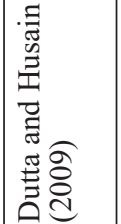 & 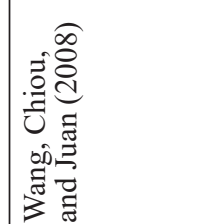 & 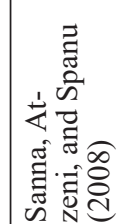 & 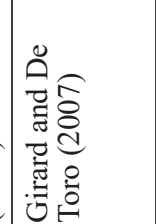 & 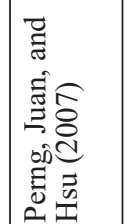 \\
\hline
\end{tabular}


Table 9. The mostly used MCDM methods in cultural heritage topic

\begin{tabular}{|l|c|}
\hline \multicolumn{1}{|c|}{ MCDM method used } & Number of times \\
\hline AHP & 20 \\
\hline Fuzzy AHP & 3 \\
\hline ANP & 8 \\
\hline Fuzzy Delphi & 4 \\
\hline Delphi & 3 \\
\hline Experts & 6 \\
\hline EDAS & 1 \\
\hline Fuzzy SAW & 1 \\
\hline ELECTRE & 1 \\
\hline Fuzzy WLC & 1 \\
\hline PROMETHEE & 2 \\
\hline WSM & 1 \\
\hline TOPSIS & 2 \\
\hline ARAS, ARAS-G & 3 \\
\hline TOPSIS Grey & 1 \\
\hline SAW & 1 \\
\hline COPRAS & 1 \\
\hline Other methods & 18 \\
\hline Combination of methods & 31 \\
\hline
\end{tabular}

A primary and in-deep analysis of the relevant papers in MCDM methods application in cultural heritage buildings area shows that the main focuses of papers are as follows: selecting appropriate reuse alternative, selecting appropriate refurbishment alternative, selecting suitable alternatives for refurbishment projects, determining level of hazards. The most used MCDM methods are AHP and fuzzy AHP, Delphi and fuzzy Delphi. Experts' knowledge is also used for the assessment of cultural heritage value and to select an optimal alternative for its conservation or refurbishment. Another popular approach in assessing cultural heritage value is using fuzzy analysis. Combination of several MCDM methods is useful in applying complex problem solving in cultural heritage buildings area.

Moreover, it was determined that AHP was used for determinate the criteria weights importance. This method is commonly applied for all type of research of applications. Fuzzy, Fuzzy Delphi, ANP and Delphi approaches applied for adaptive reuse. PROMETHEE, ARAS, SAW, TOPSIS, COPRAS used for heritage buildings preservation and renovation.

\section{Author contributions}

Z. Morkunaite was responsible for the study, related works on MCDM methods application in cultural heritage buildings area collection and analysis. She has developed a review method schema and wrote the first draft of the article. D. Kalibatas was responsible for data interpretation, obtained results analysis, conducting discussion and conclusions. He has refined the text and prepared the paper for the submission to the JCEM journal. D. Kalibatiene has developed a query for relevant data extraction from the Web of Science database and visualizes it with the VOSviewer tool.

\section{Disclosure statement}

We declare that we have no any competing financial, professional, or personal interests from other parties.

\section{References}

Ameyaw, E. E., Hu, Y., Shan, M., Chan, A. P., \& Le, Y. (2016). Application of Delphi method in construction engineering and management research: a quantitative perspective. Journal of Civil Engineering and Management, 22(8), 991-1000. https://doi.org/10.3846/13923730.2014.945953

Arksey, H., \& O’Malley, L. (2005). Scoping studies: towards a methodological framework. International Journal of Social Research Methodology, 8(1), 19-32.

https://doi.org/10.1080/1364557032000119616

Aruldoss, M., Lakshmi, T. M., \& Venkatesan, V. P. (2013). A survey on multi criteria decision making methods and its applications. American Journal of Information Systems, 1(1), 31-43.

Asadi, P., Rezaeian Zeidi, J., Mojibi, T., Yazdani-Chamzini, A., \& Tamošaitienè, J. (2018). Project risk evaluation by using a new fuzzy model based on Elena guideline. Journal of Civil Engineering and Management, 24(4), 284-300. https://doi.org/10.3846/jcem.2018.3070

Banasik, A., Bloemhof-Ruwaard, J. M., Kanellopoulos, A., Claassen, G. D. H., \& van der Vorst, J. G. (2018). Multi-criteria decision making approaches for green supply chains: A review. Flexible Services and Manufacturing Journal, 30(3), 366-396. https://doi.org/10.1007/s10696-016-9263-5

Berg, F. (2018). Wear and tear of world heritage: Preventive conservation and tourism in Norway's stave churches. Studies in Conservation, 63(sup1), 320-322. https://doi.org/10.1080/00393630.2018.1495459

Berg, F., Flyen, A. C., Godbolt, Å. L., \& Broström, T. (2017). User-driven energy efficiency in historic buildings: A review. Journal of Cultural Heritage, 28, 188-195. https://doi.org/10.1016/j.culher.2017.05.009

Berta, M., Bottero, M., \& Ferretti, V. (2018). A mixed methods approach for the integration of urban design and economic evaluation: Industrial heritage and urban regeneration in China. Environment and Planning B: Urban Analytics and City Science, 45(2), 208-232. https://doi.org/10.1177/0265813516669139

Bohnet, I. C., Roebeling, P. C., Williams, K. J., Holzworth, D., van Grieken, M. E., Pert, P. L., Kroon, F. J., Westcott, D. A., \& Brodie, J. (2011). Landscapes Toolkit: an integrated modelling framework to assist stakeholders in exploring options for sustainable landscape development. Landscape Ecology, 26(8), 1179. https://doi.org/10.1007/s10980-011-9640-0

Bozic, S., Vujičić, M. D., Kennell, J., Besermenji, S., \& Solarević, M. (2018). Sun, sea and shrines: Application of analytic hierarchy process (AHP) to assess the attractiveness of six cultural heritage sites in Phuket: Thailand. Geographica Pannonica, 22(2), 121-138. https://doi.org/10.5937/22-16983 
Cabeza, L. F., de Gracia, A., \& Pisello, A. L. (2018). Integration of renewable technologies in historical and heritage buildings: A review. Energy and Buildings, 177, 96-111. https://doi.org/10.1016/j.enbuild.2018.07.058

Cajot, S., Mirakyan, A., Koch, A., \& Maréchal, F. (2017). Multicriteria decisions in urban energy system planning: a review. Frontiers in Energy Research, 5, 10. https://doi.org/10.3389/fenrg.2017.00010

Chen, C. S., Chiu, Y. H., \& Tsai, L. (2018). Evaluating the adaptive reuse of historic buildings through multicriteria decisionmaking. Habitat International, 81, 12-23. https://doi.org/10.1016/j.habitatint.2018.09.003

Chen, Y., Yoo, S., \& Hwang, J. (2016). Fuzzy multiple criteria decision-making assessment of urban conservation in historic districts: Case study of Wenming Historic Block in Kunming City, China. Journal of Urban Planning and Development, 143(1), 05016008. https://doi.org/10.1061/(ASCE)UP.1943-5444.0000334

Claver, J., García-Domínguez, A., \& Sebastián, M. A. (2018). Decision-making methodologies for reuse of industrial assets. Complexity, 2018. Article ID 4070496. https://doi.org/10.1155/2018/4070496

Colak, M., \& Kaya, İ. (2017). Prioritization of renewable energy alternatives by using an integrated fuzzy MCDM model: A real case application for Turkey. Renewable and Sustainable Energy Reviews, 80, 840-853.

https://doi.org/10.1016/j.rser.2017.05.194

Corradi, M., Di Schino, A., Borri, A., \& Rufini, R. (2018). A review of the use of stainless steel for masonry repair and reinforcement. Construction and Building Materials, 181, 335-346. https://doi.org/10.1016/j.conbuildmat.2018.06.034

Cui, S., Yang, X., Guo, X., Lin, T., Zhao, Q., \& Feng, L. (2011). Increased challenges for world heritage protection as a result of urbanisation in Lijiang City. International Journal of Sustainable Development \& World Ecology, 18(6), 480-485. https://doi.org/10.1080/13504509.2011.603758

Culshaw, M. G., Nathanail, C. P., Leeks, G. J. L., Alker, S., Bridge, D., Duffy, T., Fowler, D., Pacjman, J. C., Swetnam, R., Wadsworth, R., \& Wyatt, B. (2006). The role of web-based environmental information in urban planning - the environmental information system for planners. Science of The Total Environment, 360(1-3), 233-245.

https://doi.org/10.1016/j.scitotenv.2005.08.037

Curtis, I. A. (2004). Valuing ecosystem goods and services: a new approach using a surrogate market and the combination of a multiple criteria analysis and a Delphi panel to assign weights to the attributes. Ecological Economics, 50(3-4), 163194. https://doi.org/10.1016/j.ecolecon.2004.02.003

Danielová, M., Kumke, H., \& Peters, S. (2016). 3D reconstruction and uncertainty modelling using fuzzy logic of archaeological structures: applied to the Temple of Diana in Nemi, Italy. Cartographica: The International Journal for Geographic Information and Geovisualization, 51(3), 137-146. https://doi.org/10.3138/cart.51.3.3160

de Almeida, A. T., Alencar, M. H., Garcez, T. V., \& Ferreira, R. J. P. (2017). A systematic literature review of multicriteria and multi-objective models applied in risk management. IMA Journal of Management Mathematics, 28(2), 153-184. https://doi.org/10.1093/imaman/dpw021

de Jalón, S. G., Iglesias, A., Cunningham, R., \& Díaz, J. I. P. (2014). Building resilience to water scarcity in southern Spain: a case study of rice farming in Doñana protected wetlands. Regional Environmental Change, 14(3), 1229-1242. https://doi.org/10.1007/s10113-013-0569-5
Dutta, M., \& Husain, Z. (2009). An application of multicriteria decision making to built heritage. The case of Calcutta. Journal of Cultural Heritage, 10(2), 237-243.

https://doi.org/10.1016/j.culher.2008.09.007

Feng, M., Liu, S., Euliss Jr, N. H., Young, C., \& Mushet, D. M. (2011). Prototyping an online wetland ecosystem services model using open model sharing standards. Environmental Modelling \& Software, 26(4), 458-468.

https://doi.org/10.1016/j.envsoft.2010.10.008

Fernandes Rocha, P., \& Calejo Rodrigues, R. (2016). Maintenance as a guarantee for roofing performance in buildings with heritage value. Buildings, 6(2), 1-15. https://doi.org/10.3390/buildings6020015

Fung, I. W., Tsang, Y. T., Tam, V. W., Xu, Y. T., \& Mok, E. C. (2017). A review on historic building conservation: A comparison between Hong Kong and Macau systems. Renewable and Sustainable Energy Reviews, 71, 927-942. https://doi.org/10.1016/j.rser.2016.12.121

Gholitabar, S., Alipour, H., \& Costa, C. M. M. D. (2018). An empirical investigation of architectural heritage management implications for tourism: The case of Portugal. Sustainability, 10(1), 93. https://doi.org/10.3390/su10010093

Girard, L. F., \& De Toro, P. (2007). Integrated spatial assessment: a multicriteria approach to sustainable development of cultural and environmental heritage in San Marco dei Cavoti, Italy. Central European Journal of Operations Research, 15(3), 281-299. https://doi.org/10.1007/s10100-007-0031-1

Giuliani, F., De Falco, A., Landi, S., Bevilacqua, M. G., Santini, L., \& Pecori, S. (2018). Reusing grain silos from the 1930s in Italy. A multi-criteria decision analysis for the case of Arezzo. Journal of Cultural Heritage, 29, 145-159. https://doi.org/10.1016/j.culher.2017.07.009

Gomes, V., Dionísio, A., \& Pozo-Antonio, J. S. (2017). Conservation strategies against graffiti vandalism on cultural heritage stones: Protective coatings and cleaning methods. Progress in Organic Coatings, 113, 90-109. https://doi.org/10.1016/j.porgcoat.2017.08.010

Govindan, K., \& Jepsen, M. B. (2016). ELECTRE: A comprehensive literature review on methodologies and applications. European Journal of Operational Research, 250(1), 1-29. https://doi.org/10.1016/j.ejor.2015.07.019

Govindan, K., Rajendran, S., Sarkis, J., \& Murugesan, P. (2015). Multi criteria decision making approaches for green supplier evaluation and selection: a literature review. Journal of Cleaner Production, 98, 66-83.

https://doi.org/10.1016/j.jclepro.2013.06.046

Govindan, K., Shankar, K. M., \& Kannan, D. (2016). Sustainable material selection for construction industry - A hybrid multi criteria decision making approach. Renewable and Sustainable Energy Reviews, 55, 1274-1288. https://doi.org/10.1016/j.rser.2015.07.100

Gregório, V., \& Seixas, J. (2017). Energy savings potential in urban rehabilitation: A spatial-based methodology applied to historic centres. Energy and Buildings, 152, 11-23. https://doi.org/10.1016/j.enbuild.2017.06.024

Gul, M., Celik, E., Aydin, N., Gumus, A. T., \& Guneri, A. F. (2016). A state of the art literature review of VIKOR and its fuzzy extensions on applications. Applied Soft Computing, 46, 60-89. https://doi.org/10.1016/j.asoc.2016.04.040

Guo, Z., Chen, W., Zhang, J., Ye, F., Liang, X., He, F., \& Guo, Q. (2017). Hazard assessment of potentially dangerous bodies within a cliff based on the Fuzzy-AHP method: a case study of the Mogao Grottoes, China. Bulletin of Engineering Geology and the Environment, 76(3), 1009-1020. https://doi.org/10.1007/s10064-016-0865-7 
Habib, C., Makhoul, A., Darazi, R., \& Couturier, R. (2019). Health risk assessment and decision-making for patient monitoring and decision-support using wireless body sensor networks. Information Fusion, 47, 10-22. https://doi.org/10.1016/j.eswa.2018.10.014

Hajkowicz, S. (2007). A comparison of multiple criteria analysis and unaided approaches to environmental decision making. Environmental Science \& Policy, 10(3), 177-184. https://doi.org/10.1016/j.envsci.2006.09.003

Hajkowicz, S. A. (2008). Supporting multi-stakeholder environmental decisions. Journal of Environmental Management, 88(4), 607-614. https://doi.org/10.1016/j.jenvman.2007.03.020

Hammarfelt, B., \& Rushforth, A. D. (2017). Indicators as judgment devices: An empirical study of citizen bibliometrics in research evaluation. Research Evaluation, 26(3), 169-180. https://doi.org/10.1093/reseval/rvx018

Han, Y., \& Wang, L. (2018). Identifying barriers to off-site construction using grey DEMATEL approach: case of China. Journal of Civil Engineering and Management, 24(5), 364-377. https://doi.org/10.3846/jcem.2018.5181

Hapciuc, O. E., Romanescu, G., Minea, I., Iosub, M., Enea, A., \& Sandu, I. (2016). Flood susceptibility analysis of the cultural heritage in the Sucevita catchment (Romania). International Journal of Conservation Science, 7(2), 501-510.

Haustein, S., \& Larivière, V. (2015). The use of bibliometrics for assessing research: Possibilities, limitations and adverse effects. In Incentives and performance (pp. 121-139). https://doi.org/10.1007/978-3-319-09785-5_8

He, Y., \& Xu, Z. (2019). Multi-attribute decision making methods based on reference ideal theory with probabilistic hesitant information. Expert Systems with Applications, 118, 459-469. https://doi.org/10.1016/j.inffus.2018.06.008

Ho, W., Xu, X., \& Dey, P. K. (2010). Multi-criteria decision making approaches for supplier evaluation and selection: A literature review. European Journal of Operational Research, 202(1), 16-24. https://doi.org/10.1016/j.ejor.2009.05.009

Hosseini, M. R., Martek, I., Zavadskas, E. K., Aibinu, A. A., Arashpour, M., \& Chileshe, N. (2018). Critical evaluation of off-site construction research: A Scientometric analysis. Automation in Construction, 87, 235-247. https://doi.org/10.1016/j.autcon.2017.12.002

Hsu, K. W., Lin, M. L., Chao, J. C., \& Huang, S. F. (2018). Constructing an evaluation framework for eco-museum operations - Management performance, based on the case of Jhushan, Taiwan. Sustainability, 10(6), 1-12. https://doi.org/10.3390/su10061934

Ibáñez, A. J. P., Bernal, J. M. M., de Diego, M. J. C., \& Sánchez, F. J. A. (2016). Expert system for predicting buildings service life under ISO 31000 standard. Application in architectural heritage. Journal of Cultural Heritage, 18, 209-218. https://doi.org/10.1016/j.culher.2015.10.006

Ipekoglu, B. (2006). An architectural evaluation method for conservation of traditional dwellings. Building and Environment, 41(3), 386-394.

https://doi.org/10.1016/j.buildenv.2005.02.009

Jajac, N., Rogulj, K., \& Radnić, J. (2017). Selection of the method for rehabilitation of historic bridges - A decision support concept for the planning of rehabilitation projects. International Journal of Architectural Heritage, 11(2), 261-277. https://doi.org/10.1080/15583058.2016.1207113

Jakimavicius, M., \& Burinskiene, M. (2007). Automobile transport system analysis and ranking in Lithuanian administrative regions. Transport, 22(3), 214-220.

https://doi.org/10.1080/16484142.2007.9638127
Junior, R. V., Varandas, S. G. P., Fernandes, L. S., \& Pacheco, F. A. L. (2014). Environmental land use conflicts: a threat to soil conservation. Land Use Policy, 41, 172-185.

https://doi.org/10.1016/j.landusepol.2014.05.012

Kang, D., \& Park, Y. (2014). Review-based measurement of customer satisfaction in mobile service: Sentiment analysis and VIKOR approach. Expert Systems with Applications, 41(4), 1041-1050. https://doi.org/10.1016/j.eswa.2013.07.101

Kaya, İ., Çolak, M., \& Terzi, F. (2018). Use of MCDM techniques for energy policy and decision-making problems: A review. International Journal of Energy Research, 42(7), 2344-2372. https://doi.org/10.1002/er.4016

Keyvanfar, A., Shafaghat, A., Mohamad, S., Abdullahi, M. A. M., Ahmad, H., Mohd Derus, N. H., \& Khorami, M. (2018). A Sustainable historic waterfront revitalization decision support tool for attracting tourists. Sustainability, 10(2), 215. https://doi.org/10.3390/su10020215

Kim, C. J., Yoo, W. S., Lee, U. K., Song, K. J., Kang, K. I., \& Cho, H. (2010). An experience curve-based decision support model for prioritizing restoration needs of cultural heritage. Journal of Cultural Heritage, 11(4), 430-437. https://doi.org/10.1016/j.culher.2010.03.004

Kitchenham, B. A., Mendes, E., \& Travassos, G. H. (2007). Cross versus within-company cost estimation studies: A systematic review. IEEE Transactions on Software Engineering, 5, 316329. https://doi.org/10.1109/TSE.2007.1001

Krishankumar, R., Ravichandran, K., Premaladha, J., Kar, S., Zavadskas, E., \& Antucheviciene, J. (2018). A decision framework under a linguistic hesitant fuzzy set for solving multicriteria group decision making problems. Sustainability, 10(8), 2608. https://doi.org/10.3390/su10082608

Krylovas, A., Kosareva, N., \& Zavadskas, E. K. (2018). Scheme for statistical analysis of some parametric normalization classes. International Journal of Computers, Communications \& Control (IJCCC), 972-987.

https://doi.org/10.15837/ijccc.2018.6.3398

Książek, M. V., Nowak, P. O., Kivrak, S., Rosłon, J. H., \& Ustinovichius, L. (2015). Computer-aided decision-making in construction project development. Journal of Civil Engineering and Management, 21(2), 248-259. https://doi.org/10.3846/13923730.2014.996250

Kumar, A., Sah, B., Singh, A. R., Deng, Y., He, X., Kumar, P., \& Bansal, R. C. (2017). A review of multi criteria decision making (MCDM) towards sustainable renewable energy development. Renewable and Sustainable Energy Reviews, 69, 596-609. https://doi.org/10.1016/j.rser.2016.11.191

Kutut, V., Zavadskas, E. K., \& Lazauskas, M. (2014). Assessment of priority alternatives for preservation of historic buildings using model based on ARAS and AHP methods. Archives of Civil and Mechanical Engineering, 14(2), 287-294. https://doi. org/10.1016/j.acme.2013.10.007

Lee, C. S., Chang, Y. C., \& Wang, M. H. (2009). Ontological recommendation multi-agent for Tainan City travel. Expert Systems with Applications, 36(3), 6740-6753. https://doi.org/10.1016/j.eswa.2008.08.016

Lee, H. C., \& Chang, C. T. (2018). Comparative analysis of MCDM methods for ranking renewable energy sources in Taiwan. Renewable and Sustainable Energy Reviews, 92, 883896. https://doi.org/10.1016/j.rser.2018.05.007

Lee, Y. C., Shiau, Y. C., \& Hsu, W. L. (2016). Applying interpretive structure modeling on the interactive correlations on factor analysis in natural and cultural scenic area at Taiwan. Artificial Life and Robotics, 21(1), 37-42. https://doi.org/10.1007/s10015-015-0245-6 
Liu, F., Zhao, Q., \& Yang, Y. (2018). An approach to assess the value of industrial heritage based on Dempster-Shafer theory. Journal of Cultural Heritage, 32, 210-220. https://doi.org/10.1016/j.culher.2018.01.011

Lubelli, B., van Hees, R. P. J., \& Bolhuis, J. (2018). Effectiveness of methods against rising damp in buildings: Results from the EMERISDA project. Journal of Cultural Heritage, 31(Supplement), S15-S22. https://doi.org/10.1016/j.culher.2018.03.025

Lucchi, E. (2016). Multidisciplinary risk-based analysis for supporting the decision making process on conservation, energy efficiency, and human comfort in museum buildings. Journal of Cultural Heritage, 22, 1079-1089. https://doi.org/10.1016/j.culher.2016.06.001

Ma, H., Li, S., \& Chan, C. S. (2018). Analytic Hierarchy Process (AHP)-based assessment of the value of non-World Heritage Tulou: A case study of Pinghe County, Fujian Province. Tourism Management Perspectives, 26, 67-77. https://doi.org/10.1016/j.tmp.2018.01.001

Maghsoodi, A. I., Abouhamzeh, G., Khalilzadeh, M., \& Zavadskas, E. K. (2018). Ranking and selecting the best performance appraisal method using the MULTIMOORA approach integrated Shannon's entropy. Frontiers of Business Research in China, 12(1), 2. https://doi.org/10.1186/s11782-017-0022-6

Malian, A., Mahdinejad, J., \& Aslani, S. (2017). Detection and documentation of the red snake by means of remote sensing techniques. Ad Alta - Journal of Interdisciplinary Research, $7(2), 125-138$.

Mardani, A., Jusoh, A., \& Zavadskas, E. K. (2015). Fuzzy multiple criteria decision-making techniques and applicationsTwo decades review from 1994 to 2014. Expert Systems with Applications, 42(8), 4126-4148.

https://doi.org/10.1016/j.eswa.2015.01.003

Mardani, A., Nilashi, M., Zakuan, N., Loganathan, N., Soheilirad, S., Saman, M. Z. M., \& Ibrahim, O. (2017a). A systematic review and meta-Analysis of SWARA and WASPAS methods: Theory and applications with recent fuzzy developments. Applied Soft Computing, 57, 265-292.

https://doi.org/10.1016/j.asoc.2017.03.045

Mardani, A., Zavadskas, E. K., Khalifah, Z., Zakuan, N., Jusoh, A., Nor, K. M., \& Khoshnoudi, M. (2017b). A review of multicriteria decision-making applications to solve energy management problems: Two decades from 1995 to 2015. Renewable and Sustainable Energy Reviews, 71, 216-256.

https://doi.org/10.1016/j.rser.2016.12.053

Mardani, A., Zavadskas, E., Govindan, K., Amat Senin, A., \& Jusoh, A. (2016). VIKOR technique: A systematic review of the state of the art literature on methodologies and applications. Sustainability, 8(1), 1-37. https://doi.org/10.3390/su8010037

Martínez-Molina, A., Tort-Ausina, I., Cho, S., \& Vivancos, J. L. (2016). Energy efficiency and thermal comfort in historic buildings: A review. Renewable and Sustainable Energy Reviews, 61, 70-85. https://doi.org/10.1016/j.rser.2016.03.018

Merschbrock, C., \& Munkvold, B. E. (2012). A research review on Building Information Modeling in construction - an area ripe for IS research. Communications of the Association for Information Systems, 31, 10, 207-228.

https://doi.org/10.17705/1CAIS.03110

Munarim, U., \& Ghisi, E. (2016). Environmental feasibility of heritage buildings rehabilitation. Renewable and Sustainable Energy Reviews, 58, 235-249.

https://doi.org/10.1016/j.rser.2015.12.334

Naziris, I. A., Lagaros, N. D., \& Papaioannou, K. (2016). Optimized fire protection of cultural heritage structures based on the analytic hierarchy process. Journal of Building Engineering, 8, 292-304. https://doi.org/10.1016/j.jobe.2016.08.007

Nicu, I. C. (2016). Cultural heritage assessment and vulnerability using analytic hierarchy process and geographic information systems (Valea Oii catchment, North-eastern Romania). An approach to historical maps. International Journal of Disaster Risk Reduction, 20, 103-111.

https://doi.org/10.1016/j.ijdrr.2016.10.015

Noryani, M. I., Sapuan, S. M., \& Mastura, M. T. (2018). Multicriteria decision-making tools for material selection of natural fibre composites: A review. Journal of Mechanical Engineering and Sciences Malaysia, 12(1), 3330-3353. https://doi.org/10.15282/jmes.12.1.2018.5.0299

Oppio, A., Bottero, M., Ferretti, V., Fratesi, U., Ponzini, D., \& Pracchi, V. (2015). Giving space to multicriteria analysis for complex cultural heritage systems: the case of the castles in Valle D'Aosta Region, Italy. Journal of Cultural Heritage, 16(6), 779-789. https://doi.org/10.1016/j.culher.2015.03.003

Ortega, J., Vasconcelos, G., Rodrigues, H., Correia, M., \& Lourenço, P. B. (2017). Traditional earthquake resistant techniques for vernacular architecture and local seismic cultures: a literature review. Journal of Cultural Heritage, 27, 181-196. https://doi.org/10.1016/j.culher.2017.02.015

Özcan, T., Çelebi, N., \& Esnaf, Ş. (2011). Comparative analysis of multi-criteria decision making methodologies and implementation of a warehouse location selection problem. Expert Systems with Applications, 38(8), 9773-9779. ttps://doi.org/10.1016/j.eswa.2011.02.022

Özdemir Işık, B., \& Demir, S. (2017). Integrated multi-criteria decision-making methods for the sustainability of historicalcultural structures on the Trabzon Coastline. Sustainability, 9(11), 2114. https://doi.org/10.3390/su9112114

Perng, Y. H., Juan, Y. K., \& Hsu, H. S. (2007). Genetic algorithmbased decision support for the restoration budget allocation of historical buildings. Building and Environment, 42(2), 770778. https://doi.org/10.1016/j.buildenv.2005.09.009

Piñero, I., San-José, J. T., Rodríguez, P., \& Losáñez, M. M. (2017). Multi-criteria decision-making for grading the rehabilitation of heritage sites. Application in the historic center of La Habana. Journal of Cultural Heritage, 26, 144-152. https://doi.org/10.1016/j.culher.2017.01.012

Pocobelli, D. P., Boehm, J., Bryan, P., Still, J., \& Grau-Bové, J. (2018). BIM for heritage science: a review. Heritage Science, 6(1), 30. https://doi.org/10.1186/s40494-018-0191-4

Pozo-Antonio, J. S., Rivas, T., López, A. J., Fiorucci, M. P., \& Ramil, A. (2016). Effectiveness of granite cleaning procedures in cultural heritage: a review. Science of The Total Environment, 571, 1017-1028. https://doi.org/10.1016/j.scitotenv.2016.07.090

Prieto, A. J., Macías-Bernal, J. M., Chávez, M. J., \& Alejandre, F. J. (2017). Fuzzy modeling of the functional service life of architectural heritage buildings. Journal of Performance of Constructed Facilities, 31(5), 04017041.

https://doi.org/10.1061/(ASCE)CF.1943-5509.0001021

Prieto, A. J., Silva, A., de Brito, J., Macías-Bernal, J. M., \& Alejandre, F. J. (2017a). The influence of pathological situations on churches' functionality: An approach based on historical records. International Journal of Architectural Heritage, 11(4), 566-587. https://doi.org/10.1080/15583058.2016.1272011

Prieto, A. J., Silva, A., de Brito, J., Macías-Bernal, J. M., \& Alejandre, F. J. (2017b). Multiple linear regression and fuzzy logic models applied to the functional service life prediction of cultural heritage. Journal of Cultural Heritage, 27, 20-35. https://doi.org/10.1016/j.culher.2017.03.004 
Radović, D., Stević, Ž., Pamučar, D., Zavadskas, E., Badi, I., Antuchevičiene, J., \& Turskis, Z. (2018). Measuring performance in transportation companies in developing countries: a novel rough ARAS model. Symmetry, 10(10), 434. https://doi.org/10.3390/sym10100434

Radziszewska-Zielina, E., \& Śladowski, G. (2017). Supporting the selection of a variant of the adaptation of a historical building with the use of fuzzy modelling and structural analysis. Journal of Cultural Heritage, 26, 53-63. https://doi.org/10.1016/j.culher.2017.02.008

Radziszewska-Zielina, E., Śladowski, G., \& Sibielak, M. (2017). Planning the reconstruction of a historical building by using a fuzzy stochastic network. Automation in Construction, 84, 242-257. https://doi.org/10.1016/j.autcon.2017.08.003

Riggio, M., D’Ayala, D., Parisi, M. A., \& Tardini, C. (2018). Assessment of heritage timber structures: Review of standards, guidelines and procedures. Journal of Cultural Heritage, 31, 220-235. https://doi.org/10.1016/j.culher.2017.11.007

Rijcke, S. D., Wouters, P. F., Rushforth, A. D., Franssen, T. P., \& Hammarfelt, B. (2016). Evaluation practices and effects of indicator use - a literature review. Research Evaluation, 25(2), 161-169. https://doi.org/10.1093/reseval/rvv038

Rosłon, J., \& Seroka, M. (2016). Multicriteria selection of water insulation technology for foundation walls in an existing building. Archives of Civil Engineering, 62(3), 167-176. https://doi.org/10.1515/ace-2015-0090

Sanmartín, P., Cappitelli, F., \& Mitchell, R. (2014). Current methods of graffiti removal: A review. Construction and Building Materials, 71, 363-374. https://doi.org/10.1016/j.conbuildmat.2014.08.093

Sanna, U., Atzeni, C., \& Spanu, N. (2008). A fuzzy number ranking in project selection for cultural heritage sites. Journal of Cultural Heritage, 9(3), 311-316. https://doi.org/10.1016/j.culher.2007.12.004

Schryen, G., Wagner, G., \& Benlian, A. (2015). Theory of knowledge for literature reviews: an epistemological model, taxonomy and empirical analysis of IS literature. In Proceedings of the Thirty Sixth International Conference on Information Systems, Fort Worth 2015 (ICIS 2015) (pp. 1-22).

Seddiki, M., Anouche, K., Bennadji, A., \& Boateng, P. (2016). A multi-criteria group decision-making method for the thermal renovation of masonry buildings: The case of Algeria. Energy and Buildings, 129, 471-483.

https://doi.org/10.1016/j.enbuild.2016.08.023

Shariati, S., Abedi, M., Saedi, A., Yazdani-Chamzini, A., Tamošaitiene, J., Šaparauskas, J., \& Stupak, S. (2017). Critical factors of the application of nanotechnology in construction industry by using ANP technique under fuzzy intuitionistic environment. Journal of Civil Engineering and Management, 23(7), 914-925.

https://doi.org/10.3846/13923730.2017.1343202

Shehada, Z. M., Ahmad, Y., Yaacob, N. M., \& Keumala, N. I. (2015). Developing Methodology for Adaptive Re-Use. Case Study of Heritage Buildings in Palestine. International Journal of Architectural Research, 9(2), 216-229.

https://doi.org/10.26687/archnet-ijar.v9i2.486

Shen, K. Y., Zavadskas, E. K., \& Tzeng, G. H. (2018). Updated discussions on 'Hybrid multiple criteria decision making methods: a review of applications for sustainability issues'. Economic Research-Ekonomska Istraživanja, 31(1), 1437-1452. https://doi.org/10.1080/1331677X.2016.1237302

Si, J., Marjanovic-Halburd, L., Nasiri, F., \& Bell, S. (2016). Assessment of building-integrated green technologies: a review and case study on applications of Multi-Criteria Decision Making
(MCDM) method. Sustainable Cities and Society, 27, 106-115. https://doi.org/10.1016/j.scs.2016.06.013

Sierra-Fernandez, A., Gomez-Villalba, L. S., Rabanal, M. E., \& Fort, R. (2017). New nanomaterials for applications in conservation and restoration of stony materials: a review. Materiales de Construcción, 67, 107.

https://doi.org/10.3989/mc.2017.07616

Sigmund, Z. (2016). Sustainability in architectural heritage: review of policies and practices. Organization, Technology \& Management in Construction: An International Journal, 8(1), 1411-1421. https://doi.org/10.1515/otmcj-2016-0007

Siksnelyte, I., Zavadskas, E., Streimikiene, D., \& Sharma, D. (2018). An overview of multi-criteria decision-making methods in dealing with sustainable energy development issues. Energies, 11(10), 2754. https://doi.org/10.3390/en11102754

Siozinyte, E., Antucheviciene, J., \& Kutut, V. (2014). Upgrading the old vernacular building to contemporary norms: multiple criteria approach. Journal of Civil Engineering and Management, 20(2), 291-298.

https://doi.org/10.3846/13923730.2014.904814

Śladowski, G., \& Paruch, R. (2017). Expert cause and effect analysis of the failure of historical structures taking into account factors that are difficult to measure. Archives of Civil Engineering, 63(2), 165-186.

https://doi.org/10.1515/ace-2017-0023

Sorvari, J., \& Seppälä, J. (2010). A decision support tool to prioritize risk management options for contaminated sites. Science of the Total Environment, 408(8), 1786-1799. https://doi.org/10.1016/j.scitotenv.2009.12.026

Stenseke, M. (2009). Local participation in cultural landscape maintenance: Lessons from Sweden. Land Use Policy, 26(2), 214-223. https://doi.org/10.1016/j.landusepol.2008.01.005

Strantzali, E., \& Aravossis, K. (2016). Decision making in renewable energy investments: a review. Renewable and Sustainable Energy Reviews, 55, 885-898.

https://doi.org/10.1016/j.rser.2015.11.021

Tam, V. W., Fung, I. W., \& Sing, M. C. (2016). Adaptive reuse in sustainable development: An empirical study of a Lui Seng Chun building in Hong Kong. Renewable and Sustainable Energy Reviews, 65, 635-642. https://doi.org/10.1016/j.rser.2016.07.014

Thorhallsdottir, T. E. (2007). Strategic planning at the national level: Evaluating and ranking energy projects by environmental impact. Environmental Impact Assessment Review, 27(6), 545-568. https://doi.org/10.1016/j.eiar.2006.12.003

Triantaphyllou, E. (2000). Multi-criteria decision making methods. In Multi-criteria decision making methods: A comparative study. Boston, MA: Springer. https://doi.org/10.1007/978-1-4757-3157-6_2

Tupenaite, L., Zavadskas, E. K., Kaklauskas, A., Turskis, Z., \& Seniut, M. (2010). Multiple criteria assessment of alternatives for built and human environment renovation. Journal of Civil Engineering and Management, 16(2), 257-266. https://doi.org/10.3846/jcem.2010.30

Turskis, Z., Morkunaite, Z., \& Kutut, V. (2017). A hybrid multiple criteria evaluation method of ranking of cultural heritage structures for renovation projects. International Journal of Strategic Property Management, 21(3), 318-329. https://doi.org/10.3846/1648715X.2017.1325782

Turskis, Z., Zavadskas, E. K., \& Kutut, V. (2013). A model based on ARAS-G and AHP methods for multiple criteria prioritizing of heritage value. International Journal of Information Technology \& Decision Making, 12(01), 45-73. https://doi.org/10.1142/S021962201350003X 
Uva, G., Sangiorgio, V., Ruggieri, S., \& Fatiguso, F. (2019). Structural vulnerability assessment of masonry churches supported by user-reported data and modern Internet of Things (IoT). Measurement, 131, 183-192.

https://doi.org/10.1016/j.measurement.2018.08.014

Valipour, A., Yahaya, N., Md Noor, N., Antuchevičienè, J., \& Tamošaitienè, J. (2017). Hybrid SWARA-COPRAS method for risk assessment in deep foundation excavation project: an Iranian case study. Journal of Civil Engineering and Management, 23(4), 524-532. https://doi.org/10.3846/13923730.2017.1281842

Vodopivec, B., Žarnić, R., Tamošaitienè, J., Lazauskas, M., \& Šelih, J. (2014). Renovation priority ranking by multi-criteria assessment of architectural heritage: the case of castles. International Journal of Strategic Property Management, 18(1), 88-100. https://doi.org/10.3846/1648715X.2014.889771

Wang, H. J., \& Zeng, Z. T. (2010). A multi-objective decisionmaking process for reuse selection of historic buildings. Expert Systems with Applications, 37(2), 1241-1249. https://doi.org/10.1016/j.eswa.2009.06.034

Wang, H. J., Chiou, C. W., \& Juan, Y. K. (2008). Decision support model based on case-based reasoning approach for estimating the restoration budget of historical buildings. Expert Systems with Applications, 35(4), 1601-1610. https://doi.org/10.1016/j.eswa.2007.08.095

Wang, W. M., Lee, A. H., Peng, L. P., \& Wu, Z. L. (2013). An integrated decision making model for district revitalization and regeneration project selection. Decision Support Systems, 54(2), 1092-1103. https://doi.org/10.1016/j.dss.2012.10.035

Webb, A. L. (2017). Energy retrofits in historic and traditional buildings: A review of problems and methods. Renewable and Sustainable Energy Reviews, 77, 748-759.

https://doi.org/10.1016/j.rser.2017.01.145
Wu, Z., \& Xu, J. (2013). Predicting and optimization of energy consumption using system dynamics-fuzzy multiple objective programming in world heritage areas. Energy, 49, 19-31. https://doi.org/10.1016/j.energy.2012.10.030

Zagorskas, J., Zavadskas, E. K., Turskis, Z., Burinskienè, M., Blumberga, A., \& Blumberga, D. (2014). Thermal insulation alternatives of historic brick buildings in Baltic Sea Region. Energy and Buildings, 78, 35-42. https://doi.org/10.1016/j.enbuild.2014.04.010

Zavadskas, E. K., Antucheviciene, J., Turskis, Z., \& Adeli, H. (2016). Hybrid multiple-criteria decision-making methods: A review of applications in engineering. Scientia Iranica, 23(1), 1-20. https://doi.org/10.24200/sci.2016.2093

Zavadskas, E. K., Govindan, K., Antucheviciene, J., \& Turskis, Z. (2016). Hybrid multiple criteria decision-making methods: A review of applications for sustainability issues. Economic Research-Ekonomska Istraživanja, 29(1), 857-887. https://doi.org/10.1080/1331677X.2016.1237302

Zavadskas, E. K., Kaklauskas, A., Kalibatas, D., Turskis, Z., Krutinis, M., \& Bartkienè, L. (2018). Applying the TOPSIS$\mathrm{F}$ method to assess air pollution in Vilnius. Environmental Engineering and Management Journal, 17(9), 2041-2050.

Zavadskas, E., Antucheviciene, J., Vilutiene, T., \& Adeli, H. (2017). Sustainable decision-making in civil engineering, construction and building technology. Sustainability, 10(1), 1-14. https://doi.org/10.3390/su10010014

Zhou, X., \& Lu, M. (2012). Risk evaluation of dynamic alliance based on fuzzy analytic network process and fuzzy TOPSIS. Journal of Service Science and Management, 5(3), 1-11. https://doi.org/10.4236/jssm.2012.53028 